\title{
Reurbanisation in Postsocialist Europe - A Comparative View of Eastern Germany, Poland, and the Czech Republic*
}

\author{
Annegret Haase, Manuel Wolff, Petra Špačková, Adam Radzimski
}

\begin{abstract}
Since the 1990s, reurbanisation has become an increasingly frequent trajectory for urban development. Many formerly shrinking cities have been able to stabilise their population or even see new growth. Especially prominent in regions like Germany and the UK, but also observed across the whole continent, a lively debate on reurbanisation has developed as a reality of today's, and a potential trajectory for tomorrow's, cities in Europe.

Postsocialist Europe has not so far been central in the reurbanisation debate, either empirically or theoretically. Subsequently, the postsocialist experience is missing in the discourse and the existing body of evidence. There is, however, some evidence that Czech and Polish cities are also seeing signs of new inner-city growth and a trend towards core city stabilisation.

Against this background, the paper scrutinises the issues of reurbanisation and new growth after the shrinking of postsocialist cities. The paper uses the approach of a contrastive comparison between cities in eastern Germany, where reurbanisation has developed as the predominant trajectory for many large cities, and for cities in Poland and the Czech Republic, where this trend is considerably less prominent. It analyses the development of reurbanisation in these cities and their urban regions over the last few decades, its characteristics and the determinants triggering or impeding it. The paper includes data on a national scale as well as from relevant case studies of cities and their urban regions.

It argues, among other things, that there is no "postsocialist model" with regard to influencing factors for reurbanisation. Eastern Germany, due to its specific postsocialist situation and transformation trajectory, can be viewed as an "outlier" or "hybrid" which exhibits characteristics typical of postsocialist and western welfare contexts and which is seeing especially dynamic reurbanisation after a phase of extreme shrinkage. Although there are clear signs of inner-city reurbanisation in Polish and Czech cities as well, it seems relatively unlikely that this process will reach the same high levels as in East German cities within the coming years.
\end{abstract}

Keywords: Reurbanisation · Large cities · Postsocialist Europe · Poland · Czech Republic · Eastern Germany

\footnotetext{
This article belongs to a special issue on reurbanisation.
}

Federal Institute for Population Research 2018

\section{(cc) BY-SA}

URL: www.comparativepopulationstudies.de DOI: $10.12765 / C P o S-2018-02$ en URN: urn:nbn:de:bib-cpos-2018-02en2 


\section{Introduction}

Across Europe, reurbanisation has evolved as a new trajectory for urban development. In different regions of the continent, formerly shrinking cities have either stabilised their population after a phase of decline or are seeing new population growth. This has manifold impacts both on their economic development and on jobs, but also on land use and housing markets as well as on the quality of life of the residents. Prominent examples of reurbanisation within the last few decades include cities in the UK and Germany, but also cities in other countries in western, central and southern Europe.

Reurbanisation is much less well-known and discussed with regard to cities in the postsocialist sphere, with the exception of eastern Germany, where many large cities have experienced new growth after a longer period of shrinking. There is, however, some evidence that Czech and Polish cities, despite continuously expanding suburbanisation, are also showing signs of new inner-city revitalisation, new in-migration to these areas, and a trend towards stabilisation of the core city (Steinführer et al. 2010).

Set against this background, the paper discusses whether reurbanisation also represents an issue or evolving trend of urbanisation in postsocialist cities. It focuses on the following guiding questions:

- How did reurbanisation evolve in the postsocialist contexts of Poland, Czech Republic and eastern Germany?

- Which factors influence the emergence and development of reurbanisation?

- How can the postsocialist reurbanisation perspective contribute to the general debate?

The paper includes data on the national sample of cities and their urban regions as well as on relevant case studies of the cities concerned. Taking a comparative perspective, the paper presents analogies and differences between the three national contexts and discusses the role and impact of reurbanisation in the postsocialist realm/context. In this regard, the role of the hinterland has been investigated in this paper as an explanatory factor for the development of the central city (e.g. suburbanisation as a reason for shrinking). Some data from the case studies, including the urban region, are presented in the annex. However, this paper focuses primarily on the development of cities and, therefore, does not explicitly address core-hinterland relations.

The paper is structured as follows: after theoretical reflections focusing on the three countries, and presentation of the materials and methods used, the development is discussed at the national scale with reference to the ten largest cities per country. Subsequently, two local case studies per country/region are analysed in greater depth with respect to meso-scale developments, interactions between city and region, as well as drivers of reurbanisation. Finally, the relevance and impact of reurbanisation are assessed for postsocialist cities, and the findings related to the international debate. 


\section{Reurbanisation in the postsocialist sphere: discussions and debates}

\section{Reurbanisation: some comments on the general debate}

Before dealing with reurbanisation in the postsocialist sphere, the following paragraphs expand briefly on the general debate about the phenomenon which has largely been dominated by western scholarly work. Reurbanisation (or "regrowth after shrinking") is not a new issue in the debate surrounding urbanisation or urban population development. The idea of a revival of (inner or core) cities within the context of former decline has already been discussed by urban researchers and planners (in the 1960s and 1970s).

Reurbanisation as a phase or stage of the urbanisation process appeared in urban life cycle models that were established in the late 1970s and in the first half of the 1980s (Berry 1977; Berg et al. 1982). At the time when the models were established, reurbanisation, was treated at a more theoretical or hypothetical level (because cities were mainly characterised by suburbanisation at that time), and reurbanisation only occurred when the core city, in contrast to its hinterland, displayed a relative or even absolute population (re)gain. The models, although still in use today, have been subjected to several improvements (Lever 1993) and criticism (Nyström 1992; Kabisch/Haase 2011).

Another strand of discussion deals with the reconcentration of population in (large) cities within the overall (regional) context of shrinkage. (Core) cities are seen as "islands of growth or stabilisation" within a largely shrinking urban landscape (Herfert 2007, on eastern Germany) or as winners in a context of continuous decline (Couch et al. 2009). According to these studies, (large) cities either remain as the only places with no decline, or initially recover, or become (in contrast to their hinterland and/or rural surroundings) destinations for in-migration due to their amenities and infrastructures. The first comparative studies on this topic discuss impact factors, drivers and lessons that can be learnt from these cities about the reasons for the change they have been undergoing (Power et al. 2010; Carter et al. 2016; Rink et al. 2012; Kabisch et al. 2012).

Other scholarly work on reurbanisation relates more to the impact of reurbanisation on the residential and economic level, as well as on housing changes in (inner) cities. These studies look at the foundations of reurbanisation and demographic, household, or housing change (Haase et al. 2010; Myers 1990; Mulder/Dieleman 2002; Karsten 2014) or the role of (inner-city) revival in the context of urban renaissance policy or neoliberal urban development (Kujath 1988; Brühl et al. 2005; Cheshire 1995, 2006; Colomb 2007; Helbrecht 1996; Storper/Manville 2006). Generally, the debate on "resurgent cities" (Cheshire 2006) and the impact of (new) population growth on different "arenas" of urban development is unfocused and, to date, such systematisations (e.g. Haase et al. 2005; Brake/Urbanczyk 2012) have merely compiled a variety of associations and contexts that relate to regrowth or reurbanisation. 


\section{Reurbanisation as a topic in postsocialist Europe}

Hitherto, the debate on reurbanisation has remained by and large a Western debate. The postsocialist perspective on reurbanisation, which is the focus of this paper, is generally underrepresented in the international discourse except for the East German case. In the following, we briefly specify how reurbanisation has been discussed in our three case study countries/regions, identifying similarities and differences in the national debates.

\section{How did reurbanisation evolve as a topic of the national urban debate?}

In eastern Germany, reurbanisation was initially discussed against the background of the shrinking that affected most of the urban sphere during the 1990s. Reurbanisation became an issue when large university cities were facing new in-migration; these cities have become trailblazers for reurbanisation. Leipzig represents the most prominent example of this development because it experienced a phase of extreme shrinking and dynamic reurbanisation in just 25 years (Rink 2015). In Germany, reurbanisation has been discussed since the 1980s (Kujath 1988). Since the 2000s, the debate has focused on, amongst other aspects, the shift of eastern German cities away from shrinking towards new growth (Herfert 2007; Haase et al. 2010). Recently, the discussion has increasingly concentrated on the new "boom of cities" in Germany and, thus, more on a new trend towards spatial development than about reurbanisation itself. Reurbanisation, in particular with regard to compaction, also emerges as an issue in the debate on urban sustainability and resource-friendly development.

The situation is different in Poland. Reurbanisation has emerged in the urban debate there, but no distinct focus has evolved so far. During the postsocialist period, the population trajectories of major cities have diversified, but either shrinking or stabilisation was observed in most cases, (Steinführer et al. 2010). Generally, suburbanisation has been the dominant trend within urban development and a key issue in urban debates. New growth of cities and/or inner-city districts is being discussed more in terms of a potential development; the use of the term reurbanisation is still relatively uncommon (Radzimski 2015). Instead, papers tend to focus on revitalisation (i.e. urban regeneration) or gentrification processes; both terms are sometimes used in conjunction with each other (Grabkowska 2015).

The situation in the Czech Republic shows greater similarities with that in Poland. Whereas urbanisation was the prevailing trajectory under socialism, urban regions have been experiencing deconcentration tendencies in the postsocialist period due to the shrinking of core cities (Sýkora/Posová 2011; Klusáček et al. 2009; Rumpel/ Slach 2012; Krejčí et al. 2011). Apart from recognisable but essentially weak counterurbanisation (Šimon 2014), the process of suburbanisation was the most significant urbanisation process in the Czech Republic, observed since the mid-1990s and peaking during the mid-2000s (Špačková/Ouředníček 2012; Sýkora/Mulíček 2014). Recent studies point to the decline of housing construction in the hinterland of large cities due to the economic crisis and a certain degree of saturation in the demand 
for this type of housing (Kubeš 2015; Kährik et al. 2016). Reurbanisation was thus explicitly mentioned in only a few studies and to a limited extent in this context (Klusáček/Vaishar 2008; Ouředníček et al. 2015).

\section{Which topics/aspects are discussed and which are not?}

In the eastern German case, research topics focused on the emergence and development of reurbanisation, its scope and speed, (mainly young and non-traditional) households driving inner-city reurbanisation, as well as inner-city neighbourhoods and housing (Haase et al. 2010, 2012; Haase/Rink 2015); topics such as the effects of reurbanisation on housing markets and inner-city regeneration/upgrading as well as the urban economy and cities as educational hubs received less attention ( Holm 2012; Kujath 2012; Gerhard 2012). Topics addressed include comparisons with other national contexts (Rink et al. 2012; Haase et al. 2010 for a cross-European sample of four cities), land use and density issues (Wolff et al. 2016) as well as compilations of indicators for detecting inner-city reurbanisation (Kabisch et al. 2010). After 2010, the debate turned to focus on the recent "boom of cities", with reurbanisation being perceived as part of this larger-scale process.

The debate in Poland has largely focused on the specific features of gentrification in Polish cities (Górczyńska 2015), the fragmentary and micro-scale character of the concentration of wealthier people in inner-city locations (Marcinczak/Sagan 2011; Marcinczak et al. 2013), or studentification in the Polish/CEE context (MurzynKupisz/Szmytkowska 2015). However, authors like to refer to the "marginal" (Gądecki 2013) nature of gentrification in Polish cities, pointing out that there are "no typical gentrifiers" (Beim/Tölle 2008). Some authors interpreted in-fill developments as evidence of reurbanisation running parallel to the dominant process of suburbanisation (Parysek/Mierzejewska 2005). Also, drawing on international debates, reurbanisation is sometimes placed in opposition to the process of gentrification (Grabkowska 2015). While reurbanisation often tends to be associated with the cyclical model of Berg et al. (1982), some recent contributions have also treated the new growth of cities as an empirical issue (Radzimski 2015) and noted rising dissatisfaction with the quality of suburban housing among younger age groups (Kajdanek 2012). Urban planning and policies still favour suburbanisation (Radzimski 2014).

In the Czech debate, studies more often drew attention to inner-city regeneration. Although neglected under socialism, inner-city neighbourhoods have attracted investment and been targeted by new in-migrants in the postsocialist period. Numerous studies either discuss the general development of inner-city neighbourhoods (Špačková et al. 2016a) or elaborate in greater detail on processes such as revitalisation, gentrification and brownfield regeneration (Sýkora 2006; Kunc et al. 2014; Frantál et al. 2015). Or they discuss the conditions for, or actors involved in, inner-city change (Steinführer 2006; Klusáček/Vaishar 2008), or the development of particular neighbourhoods and their driving forces (Temelová 2007; llik/Ouředníček 2007; Kubeš 2009). Some authors anticipate the development of reurbanisation and the weakening of suburbanisation in the future (Čermák 2009; Kubeš 2015). Qualitative investigations have revealed evolving residential preferences for inner-city 
housing by some population groups, so-called transitory urbanites (Steinführer et al. 2010; Haase et al. 2012; Kährik et al. 2016). In addition, Ouředníček et al. (2015) emphasise the potential of the "back-to-the city" movement of representatives of the second generation of suburbanites (Ouředníček et al. 2015) in contrast to their parental generation (Špačková et al. 2016b).

Concluding and cross-referencing, it is apparent that the fact that reurbanisation has not been discussed to any great extent in the postsocialist realm is due to the lack of evidence or importance attached to the subject, and that other issues like suburbanisation remain the prevailing processes of urbanisation. Eastern Germany is an exception due to its distinct and specific trajectory after 1990. Clearly, no common "postsocialist debate" on reurbanisation has developed. While the German debate developed dynamically and had an international orientation, the Polish and Czech debates remain at an initial, "incipient" stage of describing potential or smallscale new developments. In its empirical sections, the paper provides an overview of evidence on reurbanisation at the national level and selected cities of the three countries.

\section{Definitions, materials and methods}

For the purpose of this paper, reurbanisation is understood as a significant increase of the population of a city (in administrative terms), following a longer phase of decline/shrinking. In line with the urban life cycle models mentioned above, we use population development as the main indicator in order to identify where and when reurbanisation occurs. With reference to other scholarly work dealing with urbanisation trajectories in general and shrinking cities in particular, we consider population change to be a simple and frequently used indicator for representing a complex process. Moreover, it is readily accessible and comparatively easy to interpret, allowing conclusions to be drawn about adjacent processes such as household change (Beauregard 2009), or economic growth, and/or the attraction of new investment (Turok/Mykhnenko 2007). In order to clearly distinguish reurbanisation from "simple growth as such" (Cheshire 2006: 1232), our definition focuses on a longer phase of shrinking that predates the period in which shrinking comes to a halt and the population increases (again). For our analysis, this means that regrowth has to be interpreted within the context of previous shrinking/decline. We are well aware that the phenomenon of reurbanisation is much more complex and affects the fields of economic and job growth, public and private investment, and funding/ support schemes at supra-local levels. The relationships between (new) population growth and these factors will be expanded on in the second part of our empirical section, based on case studies in the three regions.

In order to meet the research objectives, we follow a two-step approach: a) Firstly, we use quantitative data to show the development of the ten largest cities per country/region, incorporating the population development of cities and their urban regions as well as the dominance of natural and/or migratory growth (data are presented in the Appendix); we thus obtain a typology of trajectories that generalise 
the population development of 30 cities into 5 types (Fig. 7). b) Secondly, we provide a more in-depth analysis of two selected case studies per country, including an examination of intra-urban developments, patterns of migration, and driving forces of reurbanisation. Using this two-dimensional approach, we believe we adequately reflect the different ways in which regrowth emerges and develops in our case study regions.

a) For the quantitative analysis at the national level, we focused on the ten largest cities per country in order to reflect the different urban systems in Poland, the Czech Republic and eastern Germany, covering various city sizes and the diverging significance of the cities within each country. In order to investigate reurbanisation phenomena and to shed light on the trajectories of each city, we used population data from 1970 to 2015 (every five years; from 1990: yearly). However, some variations occur, caused by changes in the definition of the population during a census round that have not been recalculated by the national statistical offices. This is, for example, the case in Poland (especially in Warsaw), where, from 1999 onwards, a recalculation of population numbers by the statistical office followed the 2002 population census definition), leading to variations between 1998 and 1999. ${ }^{1}$ In Germany, this is not the case because all data before the 2011 census are based on estimations. Following the 2011 census, Poland recalculated its figures which led to variations between 2009 and 2010. In Germany and the Czech Republic, variations occurred between 2010 and 2011.

Total population data were collected for the core cities and the surrounding hinterlands, which were defined by the merging of all adjacent municipalities (NUTS4; Poland: powiat, Czech Republic: okres, Germany: erweiterter Verflechtungsraum ${ }^{2}$ ). All boundaries of the spatial units have been frozen in the most recent status (2015) for which recalculations have been made. This allows comparisons over time and helps explain the role the hinterland plays in the core city development, in line with urban life cycle models (Berg et al. 1982; Cheshire 1995; Hall/Hay 1980). Finally, data on the natural evolution and migratory balance were used in order to allow conclusions to be drawn about the driving forces behind population growth and decline and, especially, about the turning points of development paths. We develop a typology of trajectories, including continuous population loss, reurbanisation, etc., for all 30 cities within the three countries in a cross-national comparison. This makes it possible to test our working definition because we take into account the previous development and compare it to the current situation.

1 This was the first census since 1988, and it revealed that, in some cases, the resident population differed significantly from the actually recorded numbers.

2 http://www.bbsr.bund.de/BBSR/DE/Raumbeobachtung/Raumabgrenzungen/Grossstadtregionen/Grossstadtregionen.html 
b) For the in-depth case studies, we chose two cities per country/region that are typical of some overarching trends and that are in line with the typology developed earlier. We chose two cities per country/region in order to a) compare and/or contrast two cases and b) detect possible anomalies which may upset the comparative picture if just one city per country/region is selected. For the selection, we applied the following criteria: a) measurable population loss of the city in the 1990 s/early 2000 s over at least 10 years; b) move towards reurbanisation within the last 5-10 years or at least visible potential for reurbanisation; c) significant role for the country/region and d) existing expert knowledge and research expertise on the selected cities. For eastern Germany, we chose Leipzig and Dresden to demonstrate the prominent change from shrinking towards reurbanisation within only a few years in a number of larger university cities. In the Czech Republic, we consider the case of the capital of Prague because it represents a valid example that explains the character and driving forces behind population regrowth in the Czech context, and the city of Brno which represents a major, non-capital city with fewer dynamics and without the role and features of a capital city. For Poland, we present the cases of Wroclaw which shows emerging reurbanisation, and Poznan which, due to the population development of the inner city, is still shrinking but has exhibited potential reurbanisation of the core city within the last few years. For all six cities, we collected population data on the intra-urban level (districts) in order to answer the questions whether and to what extent reurbanisation is spreading homogenously over the city or not. Moreover, in order to better understand the stage and emergence of reurbanisation as well as driving and hindrance processes, we present information on housing trends and preferences, local economic developments, large-scale investments and revitalisation projects and policies which is based on previous academic work, strategic documents, municipal statistics and analyses. Described trends are supported by figures where helpful or necessary, with no claim to their completeness. The type and structure of information given per case study follow a common scheme and logic without being completely identical. The main idea behind the case study descriptions is to provide comparable storylines that go beyond a national-scale quantitative analysis and illustrate the emergence and development of reurbanisation at the local level within specific city contexts, in a qualitative and explorative manner.

\section{$4 \quad$ Empirical results}

\subsection{National scale}

\section{Poland}

In the case of Poland, considerably divergent urban population developments can be observed in the postsocialist period. While cities like Łódź or Katowice experienced longer periods of shrinking, cities like Warsaw and Cracow experienced 
growth. With an increase of 63,000 residents, Warsaw was the outstanding leader in terms of growth for the period 1990-2015, whereas Łódź encountered the strongest decline (of 147,000 people). In a number of cities, including Wrocław, Poznań, Gdańsk, Szczecin and Bydgoszcz, we observe a moderate trend towards shrinking with or without growth interruptions. Wrocław and Gdańsk have been experiencing an episode of regrowth since 2010. Lublin, by contrast, continued to grow up to the late 1990s, when most other cities were already shrinking, but after 2000, it shifted from growth to decline.

The natural balance contributed negatively to the population development of most cities, with the exception of Lublin $(+7,400$ persons) and, to a smaller extent, Gdańsk. This was mainly due to the very low birth rates which prevailed in Poland throughout the postsocialist period (1.32 in 2015). The birth deficit reached its nadir between the mid-1990s and the mid-2000s. Several cities, including Warsaw, Cracow and Poznań, recently achieved a birth surplus. The increase was driven by the effect of demographic waves, with baby boom cohorts entering childbearing age. In absolute terms, Łódź lost by far the largest number of residents due to the negative natural balance $(-122,600$ inhabitants).

The overall effects of migration in Polish cities were mixed. While Warsaw, Cracow, Wrocław and Szczecin took advantage of an inflow surplus, the six other cities were confronted with a net loss. Warsaw was clearly ahead of all the other cities, with a net gain of $+128,900$ people. Poznań, by contrast, experienced the greatest net loss of -26,100 people. In most cities, out-migration started to predominate from the late 1990s onwards, and its negative effect tended to accumulate over time. More recently, this trend has been reversed, but for a number of cities (Bydgoszcz, Katowice, Lublin, Łódź and Poznań) the net effect was still negative.

Looking at the urban regions, in most cases the decline of the core cities was accompanied by a population increase in the hinterlands, resulting in a positive net overall change for the region. However, in Łódź and Katowice, the population declined also at the agglomeration level. The urban region of Warsaw experienced the largest gain of over 330,000 people. A substantial increase of almost 100,000 residents also took place in Poznań's agglomeration which is particularly striking given the ongoing shrinking of the core city.

While a number of factors are likely to have affected the postsocialist demographic trajectories of Polish cities, the role of several key factors including the economy, education, consumption patterns, planning and policies should be underlined here. In the early 2000s, the poor performance of the Polish economy, with unemployment rates peaking at 20 percent, triggered a wave of migration following the opening of labour markets in a number of EU countries. More recently, however, more favourable economic conditions again increased the incentives for migration to cities. The positive effects are, however, unevenly distributed. While cities like Warsaw and Poznań are actually facing a workforce deficit, old industrialised cities like Łódź and Katowice are still struggling to restructure their economy (Marcińczak) Sagan 2011). The economic success of Polish cities is strongly related to their performance in higher education. As an outcome of social change and a higher reputation of university education, the number of university students in Poland increased 
Fig. 1: Population development of Poland's ten largest cities 1970-2015 $(1970 / 71=100)$

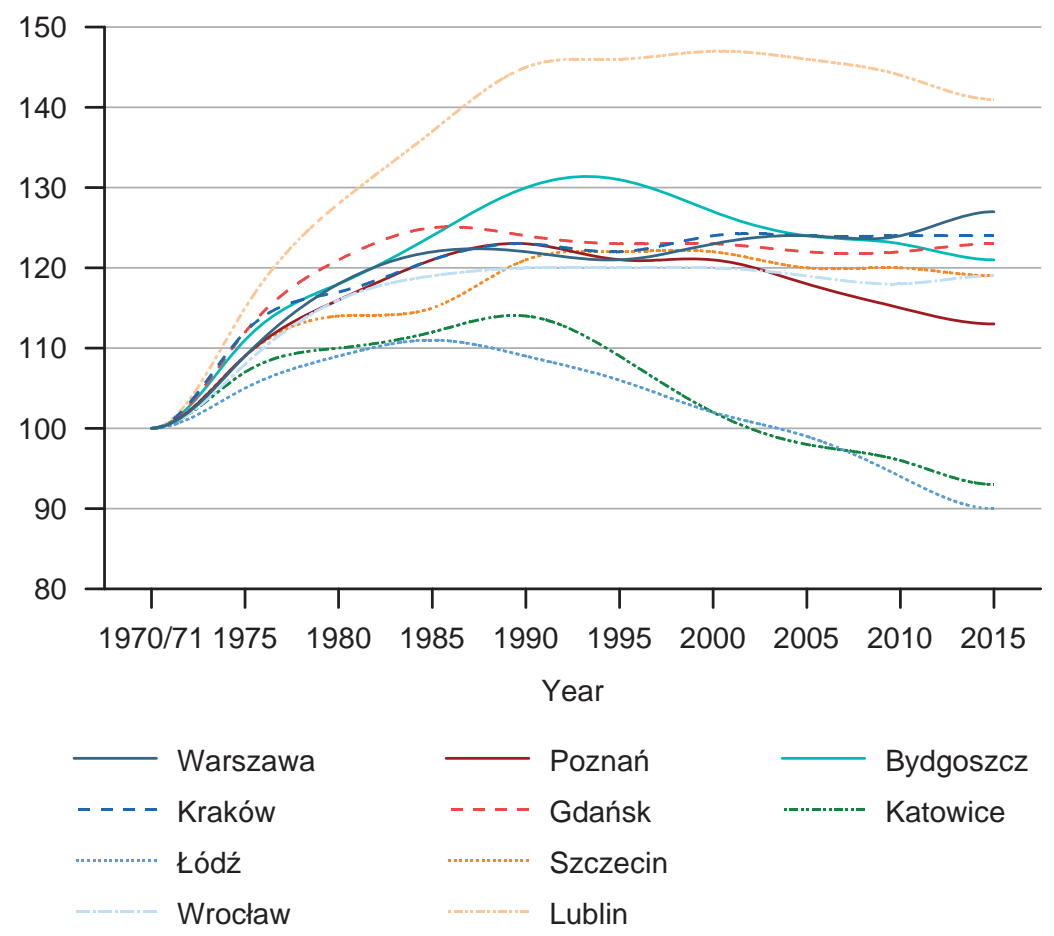

Source: Own calculation

between 1990 and the late 2000s from 400,000 to almost 2,000,000, leading to a substantial migration towards cities hosting high-ranked universities like Warsaw, Cracow, Poznań, Wrocław and Gdańsk (Sojkin et al. 2012). In short, a solid base of knowledge-intensive economy combined with educational opportunities has been one of the key determinants of rural-to-urban migration in postsocialist Poland. More recently, foreign migration has also become an important factor. Approximately one million migrants from the Ukraine were counted in Poland in 2016, making them by far the largest group of foreign migrants. Most of these migrants have arrived in the last few years following the outbreak of war in eastern Ukraine as well as the related economic depression. It is, however, difficult to estimate the impact of foreign migration at the city level, as official data are only provided at the regional level.

The positive migration effects of rural-to-urban migration were counterbalanced by a prevailing trend towards suburbanisation at the urban agglomeration level. Suburbanisation could be regarded as a spatial reflection of changing consumption patterns. For instance, the amount of outstanding mortgage debt in Poland has quadrupled in just a few years, reflecting the strong demand for home ownership (Radzimski 2014). This trend, coupled with the increasing motorisation rate and a 
deregulated land use planning system (Halleux et al. 2012), created favourable conditions for the growth of urban hinterlands.

Summing up, it can be concluded that only some of the largest Polish cities demonstrate shrinking followed by regrowth (Fig. 1). Reurbanisation tendencies are not as clearly visible as in eastern Germany. While in some cities, like Warsaw and Cracow, growth has prevailed for most of the post-transition period, other cities have encountered longer periods of shrinking. Recently, the migration balance has improved in a number of cities. However, in only two cases (Wrocław and in Gdańsk) this increase has caused a change from shrinking to regrowth. While economically motivated rural-to-urban migration creates a potential for reurbanisation, this trend is counterbalanced by (continuous) residential suburbanisation.

\section{Czech Republic}

In the last half decade, Czech cities have experienced a variety of urbanisation processes. Under socialism, strong state-led urbanisation related to the extensive construction of housing estates was dominant in urban regions (Fig. 2). Cities gained population mainly through internal migration but also as a result of the positive natural balance (primarily in the 1970s due to propopulation measures). Suburbanisation was practically non-existent and only little investment reached municipalities in the hinterlands of large cities; both processes resulted in population losses in these areas, especially during the 1980s.

After the breakdown of state socialism, almost all of the ten largest cities experienced population decline between 1990 and 2005 and lost between 2 percent and 8 percent of their 1990 population, with Ostrava and Ústí nad Labem suffering the most severe losses. The decline was driven by negative natural and migration balances alike. Two main reasons caused losses by migration. First, some cities found themselves in an unfavourable economic situation; economic decline primarily affected the cities previously dependent on heavy industry or mining (Ostrava, Ústí nad Labem). Second, the suburbanisation process was responsible for out-ofcity migration flows; it started in the region around Prague but also around many second-tier cities in the second half of the 1990s. Significant suburbanisation arose as a result of several factors. At the level of national policies, the state focused on supporting new housing construction through several measures (e.g. building savings, mortgages). The revitalisation of the pre-war housing stock was not a priority in the first years. Also, the formerly strict planning system weakened, and every municipality gained considerable planning power. As a result, the rules for housing construction were, in most cases, more flexible outside the core cities. Finally, the preference for a particular type of housing (e.g. a house with garden), which was a scarce resource under state socialism, was significant on the demand side.

Since the second half of the 2000s, some of the large cities have shown reurbanisation tendencies. The population gains were mainly driven by migration, more specifically by positive migration balances of foreigners (mostly Ukrainians, Slovaks, Russians, and Vietnamese) while ethnic Czechs continued to leave for suburbia. Furthermore, some of the cities' population increase can also be ascribed to positive natural balance, although its importance and duration varied among the cit- 
Fig. 2: Population development of the Czech Republic's ten largest cities $1970-2015(1970 / 71=100)$

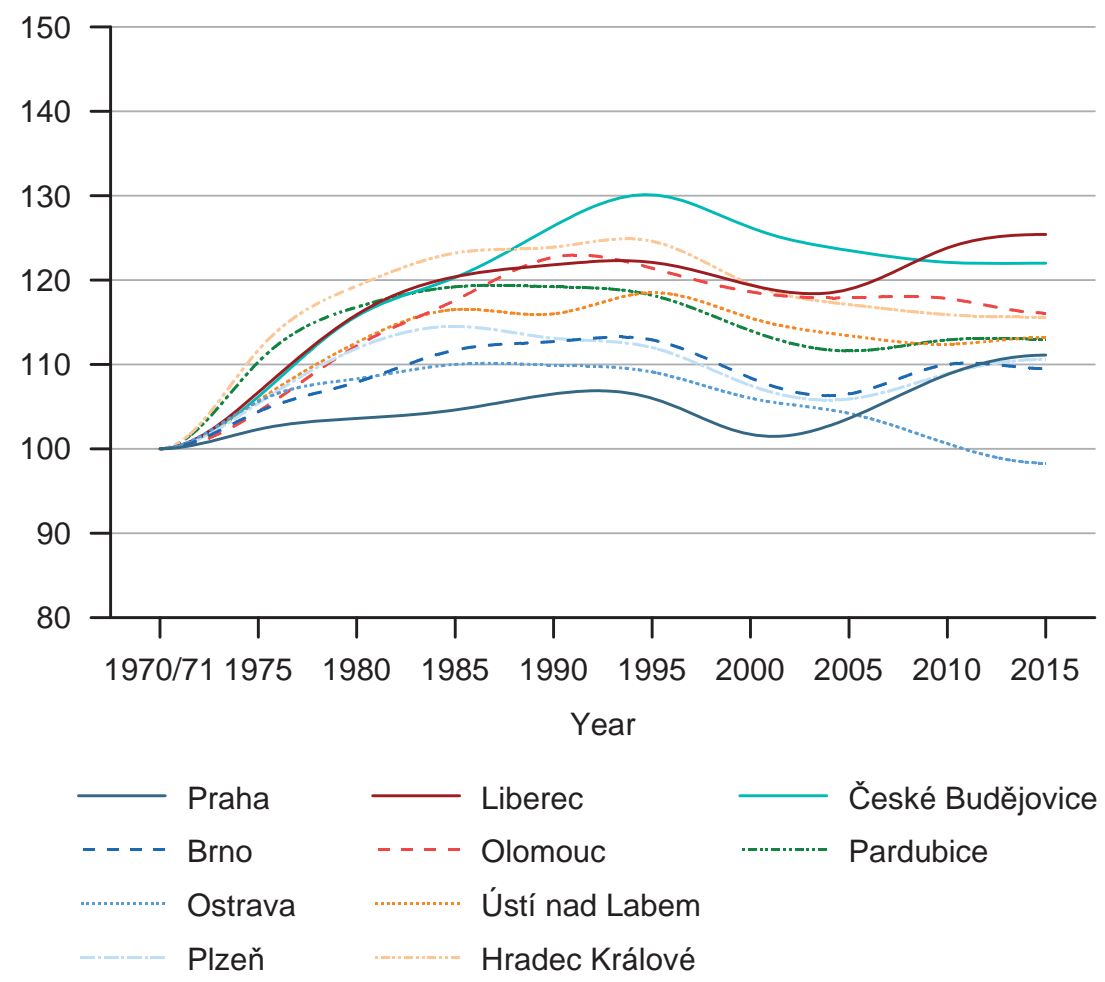

Source: Own calculation

ies. In the last decade, the urban population has experienced a "population boom", connected to strong cohorts, born in the 1970s, reaching their childbearing ages. At the same time, however, suburbanisation even increased in intensity in this period, resulting in population growth in most of the urban regions.

However, a few years after the start of the economic crisis in 2008, the growth trend was interrupted and the number of in-migrants (especially of foreigners) sharply decreased. In some cases migration losses only led to a reduction of population gains (e.g. in Prague), while other cities began to lose population again (e.g. Olomouc). Suburbanisation also slowed down as a result of lower demand for new housing. Recently, a slow reversal of trends associated with the recovery following the economic crisis can be observed. The population development of cities that previously lost population seems to have stabilised: Their losses became increasingly marginal (e.g. Brno) and some of them even turned towards reurbanisation (e.g. Plzeň).

As already indicated, the population growth in cities was mainly connected to their economic performance and the need for additional workforce which brought international immigrants to the cities (Čermák 2009). Almost all large cities exhib- 
ited a positive migration balance for the group of foreigners in the postsocialist period; its intensity was highly dependent on the economic development.

Apart from job-related migration, it was the specific housing preferences of the nascent middle classes that were responsible for continuous suburbanisation. These tendencies prevailed in most cities and their intensity was linked to the housing market dynamics (suburban housing construction). In the last few years, however, some cities also experienced stagnating out-migration juxtaposed with an increase in the number of in-migrants which led to a modest yet overall gain of population in recent years (especially in Prague, Plzeň, and Liberec). This could be considered a sign of changing housing preferences towards city-mindedness.

In sum, it should be stressed that both suburbanisation and emergent reurbanisation have coexisted in most of the Czech urban regions in the last ten years. From the regional perspective, a variegated picture of population development can be observed in the ten largest Czech cities. Prague, Plzeň, and Liberec represent exceptional examples of (almost) continuous growth during the past ten years, followed by a shorter period of decline. Ostrava has been constantly losing population since the early 1990s and is likely to see this trend continue in the future. Other cities (Olomouc, České Budějovice, Hradec Králové) experienced episodic decline. A fourth group of cities exhibited stabilisation of population development (Brno, Pardubice, Ústí nad Labem).

\section{Eastern Germany}

Reurbanisation in eastern Germany is clearly a product of the exceptional population losses of its cities. Most of the large cities in the GDR (except Potsdam and Rostock) had already ceased to grow in the 1980s; Leipzig even began to shrink in the 1960s (Fig. 3). The reasons are basically decreasing birth rates since the 1970s, out-migration due to bad housing conditions in city centres as well as out-migration as a consequence of national industrial planning policies and environmental pollution. Since 1985, seven of the ten largest eastern German cities have lost population. The exceptions are the capital Berlin and nearby Potsdam, and Rostock. With the exception of Berlin, 1990 saw the continuation and reinforcement of shrinking in every city - now dominated by East-West migration, state-funded suburbanisation and country-wide job-driven out-migration due to industrial erosion - all accompanied by a sharp decrease in (already low) birth rates to the lowest levels. Shrinking had become the predominant trajectory of urban development in eastern Germany, exhibiting dramatic dynamics. Some cities lost more than 10 percent of their populations (e.g. Chemnitz, Leipzig, Halle, Magdeburg, Erfurt).

Around 2000, the trend started to change towards reurbanisation (Fig. 3). While in many core cities the population shrinking came to a halt and the population even started to grow again, suburbanisation nearly stopped and suburban communities even began to shrink. The reasons are basically rooted in changing national policies. First, housing and living conditions have been improved due to state benefits (tax relief). Second, state funded programmes such as Stadtumbau helped to stabilise the housing market. Both interventions led to affordable and attractive housing conditions which pulled in new immigrants. Third, a lot of money was invested in the 
Fig. 3: Population development of eastern Germany's ten largest cities 1970$2015(1970 / 71=100)$

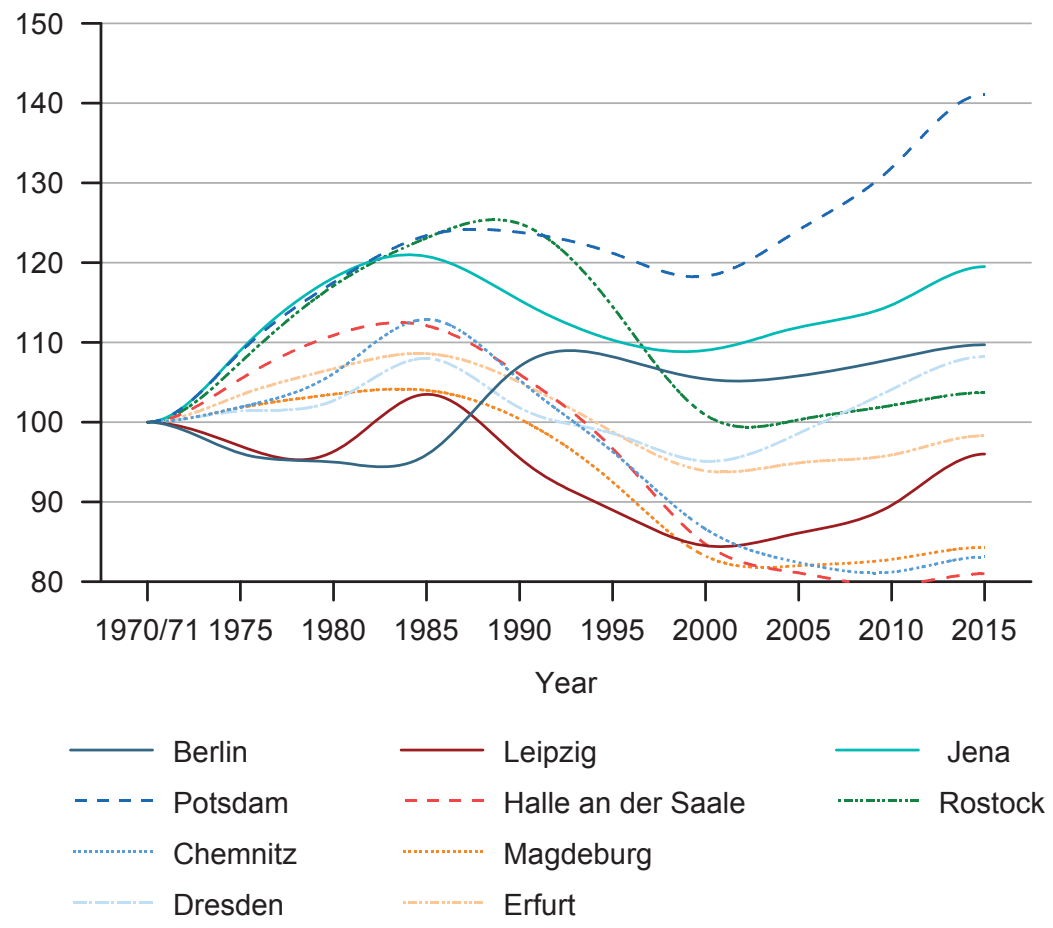

Source: Own calculation

infrastructure together with the increased relevance of universities as a guarantee of high earnings.

In contrast to the shrinking, however, reurbanisation was very heterogeneous during the 2000s. Analysis of the trajectories of all cities reveals that, despite the general shrinking trends in the 1990s and stabilisation/reurbanisation in the 2000s, and even more so in the 2010s, the population dynamics of East German cities differ considerably. The most prominent examples of the new stabilisation and growth (albeit at moderate yearly rates until the late 2000s) were cities such as Dresden and Leipzig, but also smaller university cities such as Jena, Erfurt, and Potsdam (which have regrown, not at the rates, e.g., of Leipzig, but nevertheless steadily). Subsequently, these three cities now exceed their 1970 population by $125 / 140$ percent, whereas the most prominent examples of reurbanisation, Dresden and Leipzig, exceed the 1970 population by only 8 percent (Dresden) or reached the 1970 level only in 2016 (Leipzig). However, other cities faced an even longer period of shrinking and only experienced low growth rates during the 2000s. The reasons are rooted in structural problems of the cities' economies, the lack of births and the lack of available inner-city housing; relevant examples are Rostock (ship building) and Magde- 
burg (machine construction). In contrast, shrinking rates declined in the second half of the 2000s, also in cities such as Halle that had belonged, Europe-wide, to the most dynamically shrinking cities until then. This shows that the duration and severity of shrinking have a considerable combined impact on how recovery takes place.

In the first half of the 2010s, reurbanisation became the overarching trajectory for all large cities in eastern Germany. Yearly growth rates differed; whilst some cities, such as Halle, Chemnitz, or Magdeburg, exhibited either stabilisation or very modest growth from 2011 onwards, rates have skyrocketed in Leipzig (2.5 percent since 2011) and in Dresden (1.3 percent until 2015). Whereas cities such as Jena and Potsdam - but also Berlin and Erfurt - saw a comparatively short interruption of growth through shrinking, the cities of Halle, Chemnitz, and Magdeburg have stabilised only recently at rates of approximately 80 percent of their 1970 population. The migration patterns of Germans are important for the reurbanisation currently being observed, but so, too, is legal international immigration - especially in larger cities - and refugees. Chemnitz is the initial arrival point for refugees entering the federal state of Saxony, which might have an impact on recent growth rates. Thus, for some cities it is not clear if reurbanisation is currently taking place as we have seen in Leipzig or Dresden, or if these are short-term stabilisation phenomena arising from national trends (e.g. distribution of refugees).

Thus, while the general trend towards reurbanisation is clearly due to a national trend in Germany as a whole, the differences in the time at which reurbanisation emerged and how modest/prominent the process was, depend to a marked extent on the specific situation of a city and show a clear connection to the previous period of shrinking.

\subsection{Zooming in: detecting the development in urban regions (case studies)}

\section{Poland (Poznań and Wrocław)}

Two contrasting case studies in Poland are discussed: Wrocław as an example of a recent shift towards regrowth, and Poznań where there appears to be potential for reurbanisation but where suburbanisation remains the predominant trend.

The population of Wrocław started to decline in the early 1990s, reaching its nadir in 2010 (631,000 residents). Subsequently, the number of residents increased again to 636,000 by 2015 . The population increase due to migration between 1990 and 2015 amounted to 20,000 people, i.e. more or less equal to the loss caused by natural decline. An increase in migration combined with an improving but still negative natural balance jointly contributed to the recent episode of regrowth which can be observed from 2010 onwards. Against the background of this change the local economy is thriving which has earned Wrocław a reputation as one of the most prosperous urban regions, not just in Poland but in Central and Eastern Europe as a whole. Recently, Wrocław's agglomeration attracted a number of important investors including Amazon, Google, LG and Volvo. In 2015, the registered unemployment rate was 3.3 percent. The role of the city as a centre of higher education 
is important and growing, with 120,000 students enrolled at universities, making Wrocław the third largest academic city in Poland after Warsaw and Cracow.

Looking at the intra-urban structure of the city, we find continuous shrinking in the inner city contrasted by ongoing growth in peripheral districts (Fig. 4). It appears that in Wrocław, a substantial proportion of the suburbanisation is taking place within the boundaries of the city, which comprises an area of $293 \mathrm{~km}^{2}$. Wrocław was particularly successful in fostering regulatory planning: 57 percent of the city area is covered by regulatory plans, compared to 30 percent at the national level. With 104,000 housing units approved between 2000 and 2016, the increase in housing supply in Wrocław was twice that of Poznan. At the same time, the population of the hinterlands increased by 60,000 which confirms the importance of the suburbanisation process as the predominant tendency in the Wrocław agglomeration (Książek/ Suszczewicz 2017). However, the suburbs of Wrocław grew less dynamically than those of Cracow or Gdańsk, not to mention Poznań where the increase was two times higher. As for the inner-city districts, the lack of urban regeneration measures seems to be a major factor in the continuous out-migration. An urban revitalisation programme was launched in Wrocław in 2005. However, in 2016, the city spent roughly 2.5 million euros on revitalisation projects; this is a considerable amount but far from what could be regarded as necessary for achieving comprehensive regeneration of the inner-city districts.

In Poznań, the population has declined continuously in the postsocialist period, with a tendency to accelerate over time. Despite a birth surplus in the early 2000s, the overall contribution of the natural balance was negative $(-14,000$ people). The birth deficit was coupled with a prevailing out-migration tendency which resulted in a loss of 26,000 people. In absolute terms, Poznan had the highest rate of outmigration among the ten largest Polish cities. Between 2007 and 2010, the annual net loss due to migration exceeded 3,000 people per year. Recently, the migration balance has improved somewhat, but the loss still remains substantial. In terms of the economy and the labour market, Poznan ranks comparable to or even somewhat better than Wrocław, with a registered unemployment rate of 2.4 percent in 2015. Amazon, GlaxoSmithKline, Solaris and Volkswagen are among the most important investors in the urban region. With 116,000 students, Poznan continues to be one of the major academic hubs in Poland, although recently it surrendered its third position to Wrocław.

Poznań shows a similar pattern of change in the intra-urban structure to Wrocław, with growth occurring in the outskirts and shrinking continuing in the core districts (Fig. 4). In contrast to Wrocław, however, the overall effect of these changes remains negative. The peripheral districts of Poznan appear to have absorbed a comparably low proportion of suburban migration. With a 42 percent share of the city area covered by regulatory plans, Poznań performed better than the national average, but significantly worse than Wrocław. The city also faces certain infrastructural deficiencies in the peripheral districts (Radzimski 2011). The number of housing units approved between 2000 and 2015 amounted to 51,000, which is less than one would expect in comparison to other large Polish cities. In the same period, the population of the hinterland increased by 146,000 people, placing Poznań only behind War- 
Fig. 4: Population development in Wrocław and Poznań at the district level 2000/2001-2015

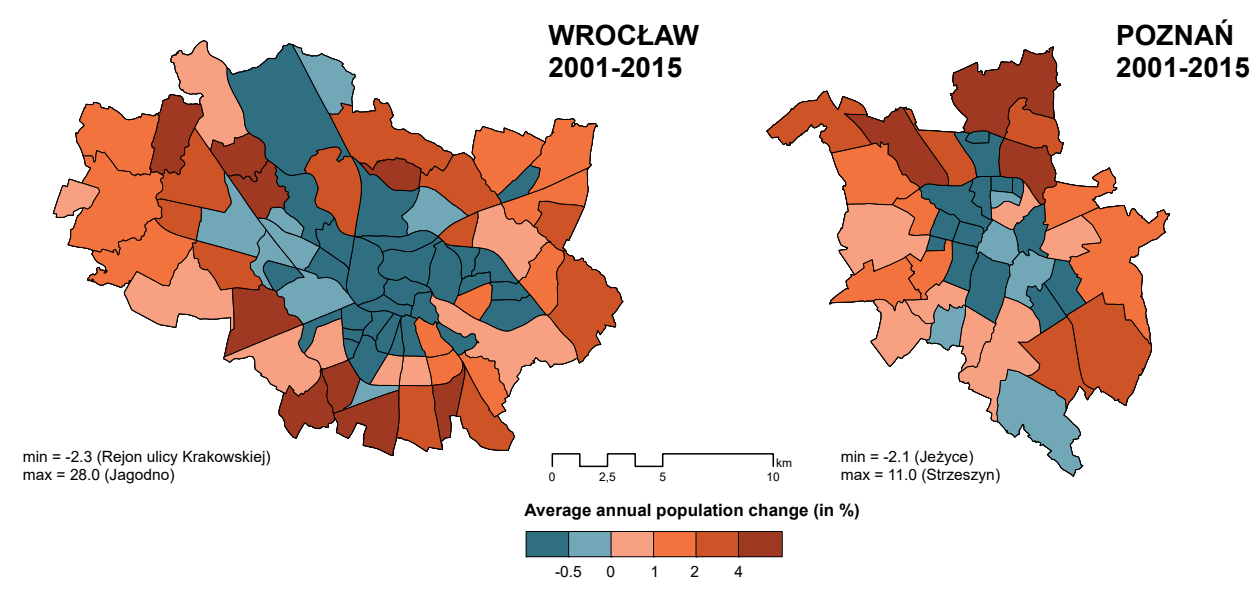

Source: Own calculation

saw in terms of suburban growth. Among the ten largest Polish cities, Poznań has the highest rate of suburban out-migration. This is probably caused by an insufficient supply of new housing on the one hand, and inadequate urban regeneration in the core districts on the other. Poznań adopted its first revitalisation programme in 2006 , but for years the regeneration process was neglected on the political agenda. In 2016, the city assigned 1.5 million euros to revitalisation projects.

Comparing the two cases, we conclude that the main difference between the population trajectories of Poznań and Wrocław was due to migration. With regard to the natural balance, both cities followed a similar trajectory, reflecting the waves of the population pyramid, with the baby-boom cohorts of the 1980s entering childbearing age around the mid-2000s and boosting the number of births. The development of migration was more differentiated and probably more dependent on local factors, as is also the case for suburbanisation. The currently prevailing demand on the housing market is driving further suburbanisation, which is likely to continue in the coming years. As we have shown for Wrocław, the proportion of suburbanisation a city accommodates within its boundaries might be a key factor shaping population trajectories. Considering reurbanisation in the inner-city districts, much will depend on the progress of urban regeneration policies and the measures taken. Also, international migration has recently emerged as an issue of potential importance for urban contexts, but little is known as yet about its spatially disaggregated effects, and its long-term significance is difficult to predict.

\section{Czech Republic (Prague and Brno)}

Whereas the reurbanisation process has not been generally strong in the last few decades, Prague represents a unique situation and can be considered a prominent example of a city which is regrowing after a short period of shrinking in the 1990s. 
Brno, on the other hand, represents "an average city" that exhibits some reurbanisation tendencies but which are regularly interrupted by periods of population losses.

After the completion of the last housing estates in the early 1990s, Prague started to lose population in 1993. The population loss was driven mainly by the negative natural balance (due to low fertility rates) and, from the late 1990s onwards, also by suburbanisation processes. The population decline continued until 2002 and Prague lost 57,000 inhabitants (almost 5 percent of the 1992 population). Since 2002, Prague has experienced relatively continuous population growth, with the most intensive gains occurring during the late 2000s. In total, Prague gained 107,000 people over the last 13 years.

This development is primarily connected to the economic boom that attracted new residents (from both other regions of the country as well as from abroad) and to the positive natural balance evident since 2006. Even though Prague's economy underwent a considerable transformation, related to deindustrialisation in the postsocialist period, the city held an exclusive position. As a capital city, Prague represents a gateway to the Czech Republic and serves as a (Central East) European centre for selected global firms (e.g. Microsoft, Hewlett-Packard, IBM, the Siemens group). The intensive concentration of progressive economic activities makes the local labour market very attractive and the unemployment rate has traditionally remained very low (Feřtrová/Temelová 2011); it reached 4.1 percent in 2016. In addition, Prague is the largest higher education hub with about 150,000 university students in 2014.

At the intra-urban level, the character of the population change has been rather varied (see Fig. 5). Some inner-city neighbourhoods started to gain population after the late 2000s, following an extended period of shrinking that was particularly intensive in the late socialist era and also continued under postsocialism due to the process of commercialisation. Population growth is recorded mainly in neighbourhoods with new housing construction. Indeed, the city's planners have recently been articulating the need for brownfield conversion and support housing developments within the compact city (e.g. Metropolitní plán 2016). In addition, considerable suburban development took place within Prague's loosely delimited administrative boundaries (comprising an area of $496 \mathrm{~km}^{2}$ ) and resulted in a dynamic population increase of 58,000 .

In the case of Brno, the population development was very similar to that of Prague under socialism and also during the 1990s. However, regrowth tendencies appeared later than in Prague and have been less stable. Brno started to gain new population only between 2008 and 2011. Subsequently, the city began to lose population again, although with less intensity, and, only from 2014 onwards did the population decrease seem to stabilise. Since the natural balance has been positive since 2006, the changes in population development are due to varying migration patterns.

First, the lower ability to retain a positive migration balance is attributable to the poor economic situation. Even though Brno was able to attract many companies from progressive economic sectors (e.g. IMB, Honeywell) its economy, which was dominated by industry at the end of the state socialist period, had difficulties in 
Fig. 5: Population development in Prague and Brno at the district level

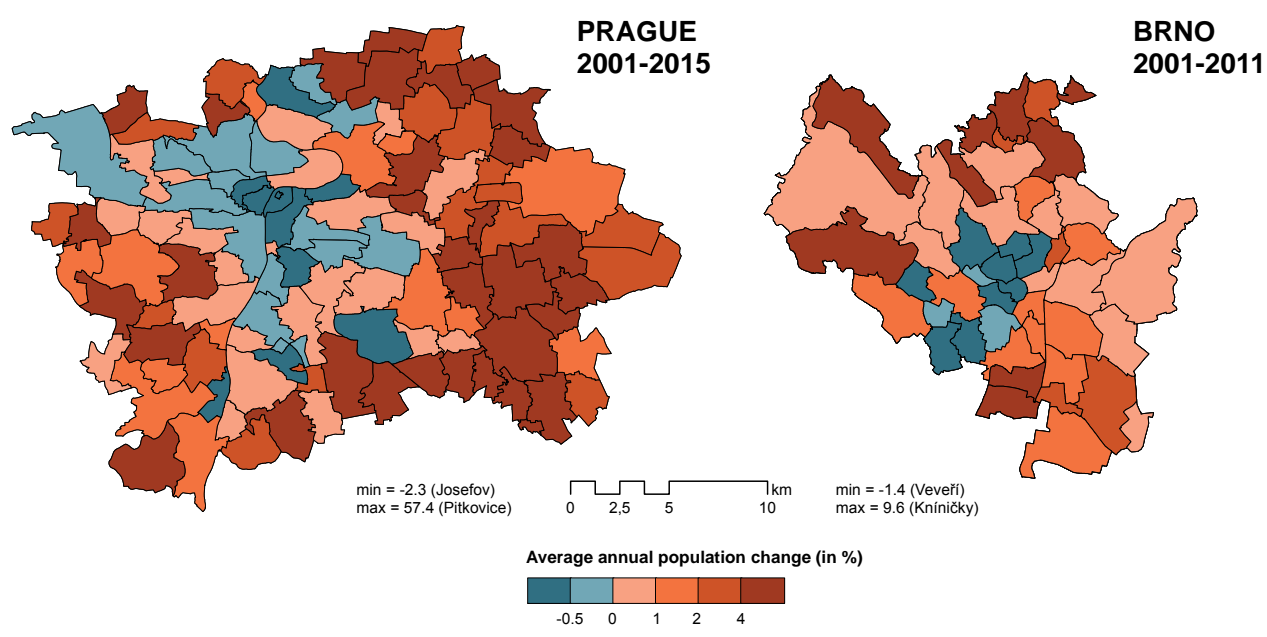

Source: Own calculation

coping with restructuring. In addition, Brno was also more seriously hit by the economic crisis that started in 2008. This is reflected in the higher unemployment rate which has varied between 7.5-9 percent since 2010.

Second, suburbanisation is also responsible for population losses, resulting in Brno's hinterland growing constantly over the past 15 years. Compared to Prague, suburbanisation within administrative boundaries has been less intensive and only accounts for approximately 15 percent of the new housing construction since 2000 (cf. 29 percent in Prague). In addition, the intensity of new housing construction is slightly lower compared to Prague; approximately 21,000 new housing units were completed between 2000 and 2015 in Brno compared to 84,000 units in Prague.

Third, because of the problem of (non)registration for permanent residency among certain sociodemographic groups, population gains may remain hidden in the official statistics (Steinführer et al. 2010). Indeed, experts estimate that the actual number of new inhabitants in Brno - including those not registered - amounts to almost 50,000, most of them unregistered persons without permanent residency and foreigners staying illegally (Seidenglanz et al. 2013). In addition, with almost 80,000 university students, Brno is the second largest academic hub in the country. Similarly to Prague, the planning authorities see potential future residential development in the revitalisation of the inner city brownfields.

Comparing the two cases, the similarity in population development derives from relatively high fertility rates. This has resulted in gains since the mid-2000s because of the positive natural balance. This is connected to the strong cohorts born in the 1970 s entering childbearing age. The main differences in the demographic trajectories result from diverse migration patterns: (i) Suburbanisation processes were mainly responsible for the negative migration balance of the (ethnic) Czechs in both cities. Whereas Brno still continues to exhibit a negative migration balance, Prague has started to experience a positive migration balance in the last two years, with 
in-migrants more often coming to the inner and outer city neighbourhoods. (ii) In the case of foreigners, the migration patterns were much more dynamic and highly dependent on the economic situation. Both cities gained foreign population during the economic boom in the mid-2000s. This changed after the economic crisis in 2008. Whilst Prague remained a relatively attractive destination for foreigners, Brno appears to have been affected more severely by the economic situation and migration gains have been only moderate. Given the favourable economic development during the past few years, the gradually increasing rate of housing construction and many ongoing and upcoming inner-city revitalisation projects, it is expected that reurbanisation tendencies will become more evident and dynamic in both cities in the near future.

\section{Eastern Germany (Leipzig and Dresden)}

In eastern Germany, reurbanisation has to be described against the background of long-term shrinking in most of the larger cities. Large university cities such as Leipzig and Dresden are the most prominent examples of reurbanisation. Massive public and private investment in the built environment and infrastructure created the preconditions for new in-migration and growth.

Leipzig saw a continuous population decline from the 1960s onwards, due to both negative natural development and out-migration. Out-migration was frequently prompted by gradual decay of the industrial base, combined with poor housing conditions and ecological degradation (Rink et al. 2012). After 1989, out-migration rates skyrocketed. From 1989 to 1998, Leipzig lost about 100,000 inhabitants. This dramatic drop in population numbers was reinforced in particular by out-migration (to western Germany) that was caused by extensive deindustrialisation. Simultaneously, Leipzig saw marked, state subsidised suburbanisation of its surrounding areas between 1994 and 1997 (Nuiss//Rink 2005). Out-migration, in total, resulted in a dramatic drop of fertility rates (as in the rest of eastern Germany). The impact of urban shrinking then became clearly visible in the vast number of brownfield sites and the large amount of vacant housing (approximately 20 percent of the total stock in 2000, Rink et al. 2012).

Shrinking came to a halt in the late 1990s and migration balances started to turn positive again due to modest but continuous in-migration throughout the whole decade of the 2000s. This occurred, first, because Leipzig underwent an administrative reform in 1999 and "regained" some of the suburbanites who had left the city years before. Second, since tax policies changed after 1997, suburbanisation declined and remained at a very modest level after 2000 (Nuiss//Rink 2005). Third, large scale refurbishment in the 1990s and early 2000s drew 80 percent of the inmigration, which led to strong population growth of these inner-city districts, while districts in the outer city continued to lose population (Fig. 6). Most of these inmigrants were young people aged 30 or less who were attracted by the availability of cheap housing (Haase et al. 2010).

Leipzig's reurbanisation was supported by massive public investment in transport, green and social infrastructures, housing, higher education, and the labour market, as well as subsidies for private investment in industries and services. Large- 
Fig. 6: Population development in the Leipzig and Dresden districts 2000-2015

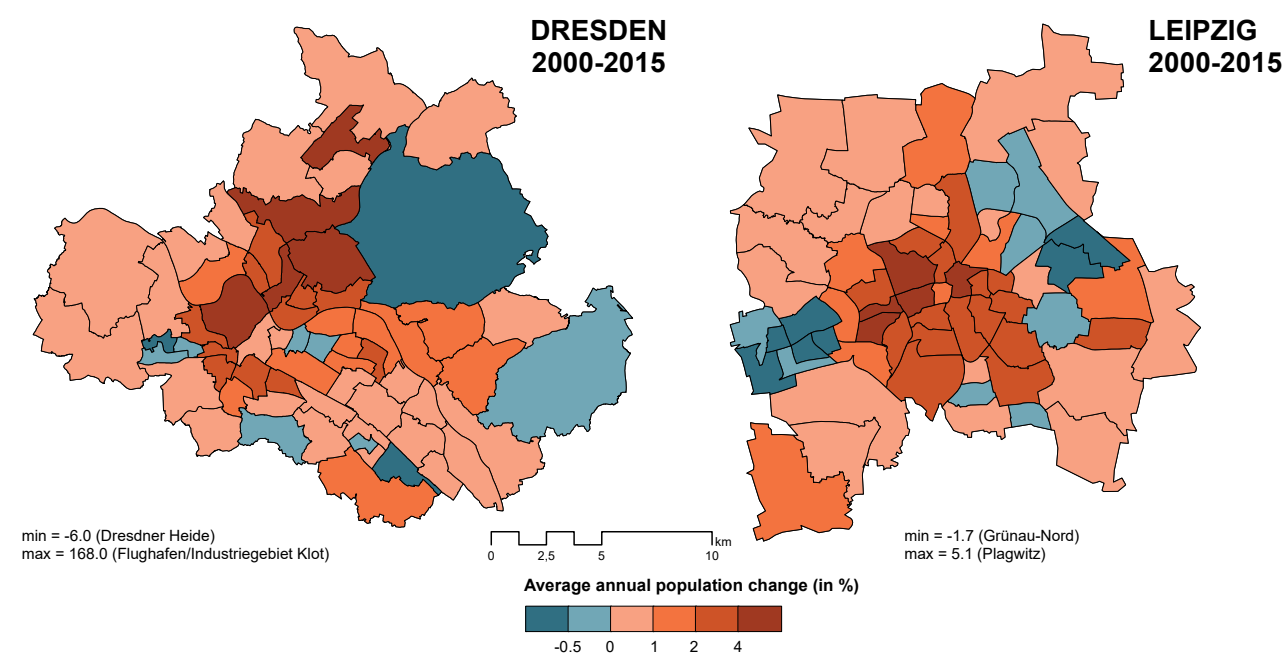

Source: Own calculation

scale investment by $\mathrm{DHL}, \mathrm{BMW}$ and Porsche, which all settled in Leipzig, were generously supported by public money; in addition, creative industries began to emerge. The city also expanded its role as a higher education hub: a bioscience park was established and existing science parks enlarged.

Reindustrialisation, new economic growth, and the creation of more than 50,000 new jobs can be viewed as the main causes of regrowth and can be interpreted as the outcomes of massive public intervention. Moreover, in the 2010s, after years of stagnation and demolition, new (upmarket) housing has been built; currently (2016) vacancies have dropped to 5 percent or less, and the housing market has moved from a supply-surplus towards a demand-surplus market (Haase/Rink 2015; Wolff et al. 2016). Since 2011, Leipzig has attracted more than 10,000 new residents yearly due to in-migration. In 2014, for the first time in decades, the city also registered a positive birth rate (see appendix). In addition, since 2015, the city has experienced an additional influx of refugees. Currently, almost all the Leipzig districts are growing or remain stable (Fig. 6), and the population was roughly 580,000 at the end of 2016. Leipzig, which was called the "capital of housing vacancy" in the early 2000s, is today amongst the fastest growing cities in Germany; the title "city of extremes" that was coined by Rink (2015) now seems very apt.

Similar to Leipzig, Dresden experienced rapid changes after reunification in terms of its economy and demography but differs from Leipzig in terms of its economic stabilisation, the role of the hinterland, and birth rates. Between 1989 and 1999 , the city lost more than 46,000 residents, basically due to out-migration and decreasing birth rates. However, 25,000 housing units were refurbished at the same time and 38,000 new housing units were built, mostly on the outskirts of the city (Wiechmann 2008). Additionally, Dresden saw intense suburbanisation during the 
1990s (see appendix). As described for Leipzig above, the combination of these processes led to high housing vacancy rates of more than 20 percent at the end of the 1990s (Wiechmann 2008). Economically, after some difficult years in the early 1990s, Dresden regained the specific role it played during the GDR era, namely as the primary location of the electronic industry, by establishing a highly competitive, high-tech industry known as the "Silicon Saxony" microelectronics cluster (Wiechmann 2008). This industry, including firms such as Infineon Technologies, together with semiconductor and component manufacturers, was supported by state subsidies; more than 760 companies were established in the region, with about 20,000 employees.

From 2000 onwards, the city experienced dynamic growth, with more than 45,000 residents being added to the statistics by 2010 . This is rooted in the renewed attractiveness of the inner city in terms of housing and public space. In Dresden's early reurbanisation phase, growing and shrinking neighbourhoods had been located side by side. In contrast, Figure 6 shows that, by the late 2000s, most of the districts experienced strong or even very strong population growth, particularly the historic neighbourhoods around the city centre. Only some districts at the fringe or with a predominance of prefabricated housing built during the GDR period still exhibited population losses. From the mid-2000s onwards, Dresden has benefited from both immigration and, for the first time since the early 1980s, rising birth rates (see appendix). By the late 2000s, Dresden's housing market came under increasing pressure with rising prices for land and rents, shortages in certain housing segments and symptoms of gentrification. It is thus not surprising that, in contrast to Leipzig, Dresden has a negative migration balance in terms of families who are pushed away from or pulled towards the hinterland of the city, which remains attractive.

When comparing the two cities, one can conclude that reurbanisation occurred when a) suburbanisation passed its peak and decreased in importance in the late 1990s and b) the core cities offered old, refurbished housing stock at moderate prices and became attractive as housing locations for city-minded (young) people. Reurbanisation started in inner-city districts with good infrastructure and valuable housing stock and spread gradually over larger areas of the cities. In eastern Germany, reurbanisation was greatly supported and boosted by investment in innercity housing stock and infrastructure. Some of these cities, including Dresden, had previously already showed signs of a stressed housing market. Leipzig, due to its large oversupply of housing, had a supply-surplus housing market until very recently and is only now slowly returning to a more stressed market. This was one of the reasons why in-migration rates in Leipzig rose dramatically after 2011, whereas the scale in Dresden remained at the 2006-10 level. In recent years Leipzig has attracted more residents from its hinterland than it has lost to it; the trend in Dresden is not as obvious due to the continuously negative migration balance for families in the hinterland. In both cities, regrowth is also expected to continue within the coming years. The potential for in-migration has increased because of more long-distance and international in-migration in recent years. However, the availability of both jobs and affordable housing will be crucial if reurbanisation is to continue. 


\section{$5 \quad$ Discussion and conclusion}

Coming back to our initial research questions and using them as a guiding principle, we summarise the results of our study in the following section and link them to the current research knowledge presented in section 2 .

\section{How did reurbanisation evolve in the postsocialist contexts of Poland, Czech Republic and eastern Germany?}

The cross-national view of the city trajectories shows that reurbanisation, understood as population growth after a longer phase of decline, can be found in postsocialist Europe. However, we observe some important variations in terms of a) the speed of the urban dynamics with regard to both previous shrinking and new growth, and b) the linear or episodic character of reurbanisation, thereby confirming previous studies (Wo/ff/Wiechmann 2017). As Figure 7 shows, which generalises the trajectories of the 10 largest cities between 1970 and 2015, we find five types of trajectories, none of which is represented in all three countries. In eastern Germany, we see an overwhelming reurbanisation trend, especially in larger cities. In addition, the trajectory of stabilisation after extreme shrinking (e.g. Madgeburg, Chemnitz, Halle) is quite typical. In contrast, shrinking is still much more widespread in Poland and the Czech Republic, even though we also find some evidence for reurbanisation tendencies in these countries (more often in the Czech Republic than in Poland). Furthermore, the three capital cities (Warsaw and Prague on the national level, Dresden at the federal state level) represent different types of trajectories. From this, we conclude that national and local contexts matter more than any "capital effects".

Remarkably, we find different city sizes throughout all types. Thus, reurbanisation does not represent a phenomenon that is primarily typical of second-rank cities; it also applies for smaller ones (e.g. Jena, Liberec). In addition, there is no clear influence of a certain city type on an urban trajectory: we find university, serviceoriented, and postindustrial cities throughout all types (reurbanising, stagnating, and shrinking).

Whilst reurbanisation has always been the overarching trend of development in larger cities in eastern Germany, the developments in Poland and the Czech Republic do not show this linearity. There are several reasons behind this differentiated development. First, shrinking has tended to be longer and more pronounced in some industrial cities, e.g. Katowice, Łódź, or Ostrava. Second, in contrast to Poland and the Czech Republic, considerable public and private investment was targeted at cities in eastern Germany. This has led to the creation of new jobs, as well as attractive housing and living conditions. Third, people in Germany are less clearly oriented towards suburban housing, compared to their Polish and Czech counterparts. Germans, however, have a preference for urban neighbourhoods that are able to offer acceptable housing and living conditions. Consequently, the intensity of suburbanisation is different in the three countries. Whilst this has had a smaller effect on the population development of core cities in eastern Germany in the past 15 years, it still plays an important role in Poland and the Czech Republic. In Poland, 
Fig. 7: Typology of population development of the ten largest cities in eastern Germany, the Czech Republic, and Poland 1970-2015

Typology of population development 1970 to 2015

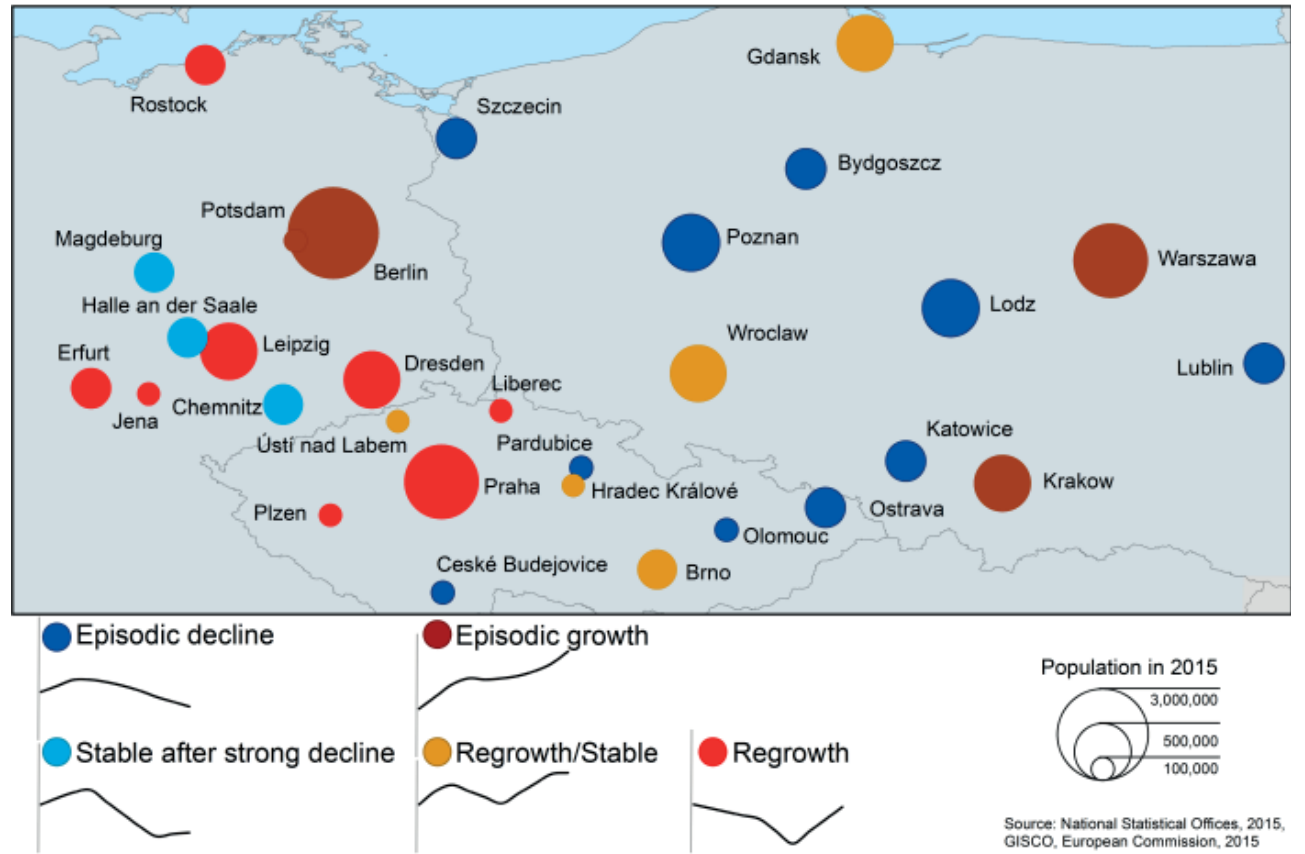

Source: Own calculation

residential suburbanisation has contributed to a situation where the economic performance and population development of a city (e.g., Poznań or, to a lesser extent, Łódź) seem to be increasingly de-coupled. This is partly due to the relative scarcity of housing supply in cities and partly to the fact that most newly built housing can be found in the suburbs. We conclude that reurbanisation in eastern Germany has been supported by active funding and investment or by pro-active internal policy, possibly combined with restrictions on suburban developments (e.g. abolition of the state/federal subsidy for builders of private housing in Germany in 2006).

\section{When looking at the case studies, we found both commonalities and differences.}

First, there are variations in the profiles of in-migrants. Generally, reurbanisation is driven by younger age groups in their early twenties who, however, might leave the cities after completing their education. Therefore, career starters and families are considered much more significant for (long-term) reurbanisation. However, they play a different role in the individual case studies which is due to different housing histories, as well as to the availability and affordability of inner-city housing and its alternatives (e.g. in the suburbs). Moreover, reurbanisation, measured simply by 
population growth, might be unstable. In the Czech case, the evidence shows that reurbanisation (in terms of population) is closely linked to international population in- and outflows, which, in turn, are dependent on economic developments. In contrast, this aspect plays a minor role in Poland. This shows the important role of different types of in- and immigration flows for reurbanisation and indicates the need for further in-depth research.

Second, national-scale developments are reflected differently within the cities. In all three countries we see inner-city neighbourhoods as starting points for reurbanisation. Overall trends of changing housing preferences and rising city-mindedness, especially among middle-class urban dwellers, are emerging. In the case of Poland and the Czech Republic, this is still not particularly evident in terms of (long-term) data, but it is clearly underway in cities in these countries (see also earlier studies on transitory urbanites by Haase et al. 2011, 2012; Kährik et al. 2016).

Generally, there are two factors driving inner-city reurbanisation in eastern Germany and slowing it down or delaying it in Poland and the Czech Republic: different tenure structures and different urban/suburban housing history orientations. Reurbanisation in eastern Germany was fostered by high residential mobility rates, which are more likely to be found in a tenants' market. By contrast, the housing markets in Poland and the Czech Republic are shaped by a preference for owner-occupied housing. In addition, housing histories in these two countries are more often suburboriented, which is connected to the long-term preference for a family house with a garden, the lack of affordable, family-oriented housing in core cities, and the absence of effective internal development policies. Another factor that indirectly impacts the level of in-migration to cities, at least in the Czech Republic, is the economic situation because in-migration is driven to a large extent by (labour) immigration. The effect of, e.g., the 2008 crisis was, thus, to interrupt in-migration into large cities.

\section{Which factors are influencing the emergence and development of reurbanisation?}

Table 1 summarises the factors that we identified as decisive/relevant with respect to their influence on the emergence and development of reurbanisation in the three countries. We identified four main complex factors or bundles of factors that are driving the emergence and development of reurbanisation in the three countries and that allow conclusions on its duration and persistence.

1. Population growth and its components: Population growth of the core cities is evident in the emergence and development of reurbanisation in all cases, and is especially prominent in eastern Germany. Both domestic and international migration plays a role, although more prominently in eastern Germany and the Czech Republic. ${ }^{3}$ While in eastern Germany the majority of in-migrants target the core city, in Poland and the Czech Republic in-migration is concentrated

3 In Poland, foreign immigration has only emerged as a factor since 2014, mainly through migration from (eastern) Ukraine. 
rather on the suburbs, mainly due to a lack of affordable housing in the core city. Within recent years natural growth has become a factor that could have a greater impact in the long run; in Poland and the Czech Republic, however, much of the natural growth is "moving" with young families to the suburbs.

2. Strategic policy orientations including control of suburbanisation: The case of eastern Germany shows that a combination of support for inner-city housing and delimitation of suburbanisation may foster reurbanisation. The lack of consistent policies for the support of cities both at the national and the local level in Poland and the Czech Republic is clearly one of the factors hindering core city growth. EU-funding may have different effects here: while respective funds were used in East German cities to strengthen urban neighbourhoods, in the other two cases, selective measures aimed at supporting suburban housing construction have been financed. In Poland and the Czech Republic, there is a connection between ongoing suburbanisation and the lack of affordable inner-city housing.

3. Investment-economy-job nexus: Investment is a factor in all cases but has different sources, magnitudes and effects. While in the two East German case studies a combination of public and private investment basically into infrastructure and service economies led to the creation of new jobs (after heavy losses in the 1990s) that allowed in-migrants to stay, the Czech and Polish cities attract people with their job opportunities; many of those residents, however, live in or go to the suburbs. Support schemes also differ - and range from large public subsidies and support for the settlement of private business in eastern Germany to special economic zones with infrastructure and tax relief in Poland and the Czech Republic.

4. Supply of inner-city housing: While investment in inner-city housing in eastern Germany led to moderately priced rented housing which meets the needs of in-migrants, investment into housing in the other two countries led mostly to gentrification and not to a decrease in the lack of affordable housing. Therefore, investment in the housing stock combined with a different tenure structure has led to quite different outcomes: as a "push factor" in eastern Germany, on the one hand, and as a "hindering factor" in the two other examples, on the other, at least up to the present.

In summary, it is obvious that there is no "postsocialist model" with regard to the influencing factors of reurbanisation. At the same time, it is apparent that eastern Germany, due to its specific postsocialist condition and transformation, should be viewed as an "outlier" or "hybrid" showing characteristics typical of postsocialist and western welfare contexts, plus the specifics of extreme shrinking and especially dynamic reurbanisation. We did not subdivide "amenities" into educational and cultural/tourist facilities, open spaces and infrastructures in the table since it is almost impossible to single out general aspects of their impact apart from local specifics. We wish to underline, however, that those amenities also influence reurbanisation, since they are more (as in the German case) or less (as in the Czech Republic and Poland) directly connected with housing and quality of life. 
Tab. 1: Factors influencing the emergence and development of reurbanisation in the three countries

\begin{tabular}{|c|c|c|c|}
\hline Factor & eastern Germany & Poland & Czech Republic \\
\hline Migration & $\begin{array}{l}\text { reurbanisation almost } \\
\text { exclusively driven by } \\
\text { in-migration, until } 2010 \\
\text { largely regionally- } \\
\text { based, since } 2010 \text { with } \\
\text { increasingly national } \\
\text { and international } \\
\text { background; in-migration } \\
\text { has led to rejuvenation; } \\
\text { reasons are education } \\
\text { and, after } 2010 \text {, } \\
\text { increasingly migration by } \\
\text { professionals; since } 2010 \\
\text { new suburbanisation as } \\
\text { a by-product of core city } \\
\text { growth }\end{array}$ & $\begin{array}{l}\text { out-migration to the } \\
\text { suburbs remains } \\
\text { predominant; it is } \\
\text { accompanied by incipient } \\
\text { (localised) reurbanisation } \\
\text { (in terms of in-migration); } \\
\text { from } 2015 \text { onwards, } \\
\text { international migration } \\
\text { has emerged as an issue } \\
\text { in employment statistics }\end{array}$ & $\begin{array}{l}\text { in-migration during mid- } \\
2000 \text { s and mid-2010s } \\
\text { mostly job-based, partly } \\
\text { domestic and partly } \\
\text { international migration; } \\
\text { suburbanisation remains } \\
\text { predominant trend }\end{array}$ \\
\hline $\begin{array}{l}\text { Natural } \\
\text { population } \\
\text { development }\end{array}$ & $\begin{array}{l}\text { 2010s: natural growth } \\
\text { becomes a factor } \\
\text { (combination of } \\
\text { increased birth rates and } \\
\text { higher likeliness of young } \\
\text { in-migrants to stay) }\end{array}$ & $\begin{array}{l}\text { no substantial effect of } \\
\text { natural growth as families } \\
\text { continuously move out to } \\
\text { the suburbs }\end{array}$ & $\begin{array}{l}\text { moderate natural } \\
\text { growth since the second } \\
\text { half of 2000s (cohort } \\
\text { effect); suburbanisation } \\
\text { "moves" part of this } \\
\text { growth out of the cities }\end{array}$ \\
\hline $\begin{array}{l}\text { Public } \\
\text { investment }\end{array}$ & $\begin{array}{l}\text { indispensable } \\
\text { for creation of } \\
\text { reurbanisation-friendly } \\
\text { conditions, long-term, } \\
\text { substantial, including } \\
\text { direct investment and } \\
\text { subsidies (e.g. for } \\
\text { housing, transport and } \\
\text { infrastructure) }\end{array}$ & $\begin{array}{l}\text { substantial EU- } \\
\text { funded infrastructural } \\
\text { investment, but favoured } \\
\text { suburbanisation }\end{array}$ & $\begin{array}{l}\text { no major public } \\
\text { investment focused } \\
\text { on core/inner cities; } \\
\text { subsidies for mortgage } \\
\text { loans and building } \\
\text { savings (suburban } \\
\text { housing) }\end{array}$ \\
\hline $\begin{array}{l}\text { Private } \\
\text { investment }\end{array}$ & $\begin{array}{l}\text { important in some } \\
\text { sectors (e.g. economy, } \\
\text { housing), often in } \\
\text { combination with } \\
\text { public investment } \\
\text { and subsidies, or for } \\
\text { exploiting their results/ } \\
\text { conditions }\end{array}$ & $\begin{array}{l}\text { new, mostly suburban, } \\
\text { housing construction, } \\
\text { some high-profile } \\
\text { projects in inner-city } \\
\text { locations }\end{array}$ & $\begin{array}{l}\text { important; new housing } \\
\text { construction in all parts } \\
\text { of the cities and urban } \\
\text { regions }\end{array}$ \\
\hline $\begin{array}{l}\text { Jobs and } \\
\text { economic } \\
\text { development } \\
\text { (various } \\
\text { sectors) }\end{array}$ & $\begin{array}{l}\text { considerable job } \\
\text { creation in various } \\
\text { sectors decisive for the } \\
\text { settlement and retention } \\
\text { of potential families in } \\
\text { the city; large-scale } \\
\text { economic investment } \\
\text { decisive for job creation }\end{array}$ & $\begin{array}{l}\text { job opportunities attract } \\
\text { new residents to the } \\
\text { urban regions but, due } \\
\text { to inadequate/expensive } \\
\text { supply in the core city, } \\
\text { many go to the suburbs }\end{array}$ & $\begin{array}{l}\text { job opportunities } \\
\text { decisive for domestic } \\
\text { and international in- } \\
\text { migration; some new } \\
\text { in-migrants leave for } \\
\text { suburbs after starting } \\
\text { family }\end{array}$ \\
\hline
\end{tabular}


Tab. 1: Continuation

\begin{tabular}{|c|c|c|c|}
\hline Factor & eastern Germany & Poland & Czech Republic \\
\hline $\begin{array}{l}\text { Housing } \\
\text { market - } \\
\text { a) supply }\end{array}$ & $\begin{array}{l}\text { availability of refurbished } \\
\text { inner-city housing for } \\
\text { moderate rents decisive } \\
\text { for new in-migration; } \\
\text { tenure (rental) eased } \\
\text { high residential mobility; }\end{array}$ & $\begin{array}{l}\text { shortage and costly } \\
\text { refurbishment of old } \\
\text { established housing; } \\
\text { dominance of home } \\
\text { ownership limits } \\
\text { residential mobility; }\end{array}$ & $\begin{array}{l}\text { long-term rent } \\
\text { regulation (until 2012) } \\
\text { and home ownership } \\
\text { limit residential } \\
\text { mobility; shortage of } \\
\text { affordable inner-city } \\
\text { housing; continuity }\end{array}$ \\
\hline $\begin{array}{l}\text { b) demand, } \\
\text { preferences }\end{array}$ & $\begin{array}{l}\text { city-based housing } \\
\text { preferences and } \\
\text { dominance of rental } \\
\text { housing support } \\
\text { reurbanisation: made } \\
\text { people stay and attracted } \\
\text { new residents }\end{array}$ & $\begin{array}{l}\text { predominant focus on } \\
\text { meeting needs and } \\
\text { saving costs; home } \\
\text { ownership preferred }\end{array}$ & $\begin{array}{l}\text { of suburban housing } \\
\text { preference; home } \\
\text { ownership preference; } \\
\text { preference change } \\
\text { towards city-centre }\end{array}$ \\
\hline $\begin{array}{l}\text { Strategic } \\
\text { policy } \\
\text { orientations }\end{array}$ & $\begin{array}{l}\text { local pro-reurbanisation } \\
\text { policies since early } \\
2000 \text { s, cancellation of } \\
\text { national subsidies for } \\
\text { housing suburbanisation } \\
\text { in } 2006\end{array}$ & $\begin{array}{l}\text { lack of general policy } \\
\text { orientation towards cities } \\
\text { on national and local } \\
\text { level; selective "pro- } \\
\text { suburbani-sation" policies } \\
\text { such as subsidised } \\
\text { mortgage loans }\end{array}$ & $\begin{array}{l}\text { lack of general policy } \\
\text { orientation towards } \\
\text { cities; selective "pro- } \\
\text { suburbanisation" } \\
\text { policies such as } \\
\text { subsidised mortgage } \\
\text { loans and buildings } \\
\text { savings }\end{array}$ \\
\hline
\end{tabular}

Source: Own calculation

\section{How can the perspective on postsocialist reurbanisation fertilise the general debate?}

From our study, we conclude that reurbanisation exists as a phenomenon in all three countries. However, we have not identified a common postsocialist type of reurbanisation and there are considerable differences between cities that can be partly explained by national differences. Whilst we see a "city boom" in eastern Germany and a general "turn from shrinking towards reurbanisation" of large cities, we could not detect similar developmental patterns/processes in Poland and the Czech Republic.

Considering the sum of factors influencing the development of reurbanisation, it seems relatively unlikely that reurbanisation will reach prominent levels in Poland and the Czech Republic within the coming years. However, we currently observe a "de-coupled" development of economic performance and population development: some cities are economically successful and simultaneously continuing to lose population (e.g. in the Polish cases). This raises two major questions for further research: Is this specific to postsocialist cities or can we also detect such a trend outside the postsocialist realm? And: Is it appropriate only to use population data to detect or explore reurbanisation? Can we rely solely on this indicator or is there a need for a more complex, multi-dimensional measure?

When reflecting on the specificity of the postsocialist condition, we see that eastern Germany plays a special role. The country has been experiencing very strong regrowth since 2010, subsequent to a sharper decline than in many western Euro- 
pean regions, including western Germany. The decline was inevitably connected to the postsocialist condition of eastern Germany. In none of the non-postsocialist regions of Europe has there been a break or turn around like the one that occurred in 1989/90 in the state socialist countries. At the same time as welfare policies and public investment in eastern Germany were supporting reurbanisation, the strong orientation towards neoliberalism, privatisation, and a suburb-oriented consumption model (expansion of the mortgage market, the rise in motorisation rates) privileged suburbanisation in Poland and the Czech Republic and slowed down reurbanisation tendencies. Whereas most policies supporting suburbanisation were phased out by the mid-2000s in eastern Germany, such policies are still being pursued in the two other countries. A more neoliberal orientation and withdrawal of the state from the support of local development highlights a clear distinction between regions in the UK, or even in the US and postsocialist Europe (except eastern Germany). Bearing these developments in mind, we argue that eastern Germany represents a specific ("hybrid") case of postsocialist development.

In sum, reurbanisation in our three countries exhibits many underlying factors and dynamics that are identical or very similar to those we know from Western Europe. Given this context, we conclude that there is no specific "postsocialist reurbanisation" type. However, the postsocialist history of a country, as an impact factor on long-term developments, has to receive more attention within the general debate, because it explains certain divergences from western models of the developments in the three countries as well as differences between the countries.

Our contribution provided a description, analysis, and synthesis based on national-scale and case study data. To gain deeper insights, more in-depth research is needed which would require at least one additional investigation. Future research should, in particular, shed more light on cause-effect relationships between the drivers mentioned and should enhance knowledge on the role of framework developments and the roles/effects of policies. In addition, it should consider the interplay of multiple scales and multi-scalar effects on local developments in greater detail. Future research should also take a more systematic view of analogies and differences between postsocialist cases, e.g. by means of a contrasting comparison.

\section{Acknowledgements}

The authors would like to thank the anonymous reviewers for their valuable comments and suggestions, and the editors for their support with the manuscript. Petra Špačková thanks for support to the Czech Science Foundation under project no. 1620991S and also to Charles University Research Centre program UNCE/HUM/018. Manuel Wolff would like to thank the Charles University, Prague, for a research grant which enabled him to contribute to this paper. 


\section{References}

Beim, Michał; Tölle, Alexander 2008: Segregationsprozesse zwischen Altbauverfall und Suburbanisierung. Das Beispiel Posen. [Segregation processes between declining older buildings and suburbanisation - case study Posen.] In: disP - The Planning Review 174,44: 51-65 [doi: 10.1080/02513625.2008.10557016].

Beauregard, Robert A. 2009: Urban population loss in historical perspective: United States, 1820-2000. In: Environment and Planning A, 41,3: 514-528 [doi: 10.1068/ a40139a].

Berg, Leo van den et al. 1982: Urban Europe. A Study of Growth and Decline. Vol. 1. Oxford: Pergamon Press.

Berry, Brian J. L. 1977: Urbanization and Counter Urbanization. London: Sage.

Bradbury, Katharine et al. 1982: Urban Decline and the Future of American Cities. Washington, DC: Brookings Institution.

Brake, Klaus; Urbanczyk, Rafael 2012: Reurbanisierung - Strukturierung einer begrifflichen Vielfalt. In: Brake, Klaus; Herfert, Günter (Eds.): Reurbanisierung. Wiesbaden: VS Verlag: 34-51 [doi: 10.1007/978-3-531-94211-7_3].

Brühl, Hasso et al. 2005: Wohnen in der Innenstadt - eine Renaissance? Difu-Berichte zur Stadtforschung 41. Berlin: Deutsches Institut für Urbanistik.

Carter, Donald K. 2016 (Ed.): Remaking Post-Industrial Cities. Lessons from North America and Europe. Routledge.

Čermák, Zdeněk 2009: Současné tendence vývoje obyvatelstva metropolitních areálů v česku: Dochází k významnému obratu? In: Geografie 114,1: 37-51.

Cheshire, Pau/ 1995: A new phase of urban development in Western Europe? The evidence for the 1980s. In: Urban Studies 32,7: 1045-1063 [doi: 10.1080/00420989550012564].

Cheshire, Paul C. 2006: Resurgent cities, urban myths and policy hubris: what we need to know. In: Urban Studies 43,8: 1231-1246 [doi: 10.1080/00420980600775600].

Colomb, Claire 2007: Unpacking New Labour's 'urban renaissance' agenda: towards a socially sustainable reurbanisation of British cities? In: Planning, Practice \& Research 22,1: 1-24 [doi: 10.1080/02697450701455249].

Couch, Chris; Fowles, Steven; Karecha, Jay 2009: Reurbanization and housing markets in the central and inner urban areas of Liverpool. In: Planning Practice \& Research 24,3: 321-341 [doi: 10.1080/02697450903020767].

Feřtrová, Marie; Temelová, Jana 2011: Prostorová specifi ka strukturální nezaměstnanosti na úrovni obcí v České republice. Sociologický časopis/Czech Sociological Review 47,4: 681-716.

Frantál, Bohumil et al. 2015: Exploring spatial patterns of urban brownfields regeneration: The case of Brno, Czech Republic. In: Cities 44: 9-18 [doi: 10.1016/j.cities.2014.12.007].

Gądecki, Jacek 2013: Odkrywając miasto idealne? Marginalna gentryfikacja starej części dzielnicy Nowa Huta. [Discovering the ideal city. Marginal gentrification in the old part of the Nowa Huta district.] In: Studia Regionalne i Lokalne 54,4: 64-81 [doi: 10.7366/1509499545404].

Gerhard, Ulrike 2012: Reurbanisierung - städtische Aufwertungsprozesse in der Global-City-Perspektive. In: Brake, Klaus; Herfert, Günter (Eds.): Reurbanisierung. Materialität und Diskurs in Deutschland. Wiesbaden: Springer: 52-68 [doi: 10.1007/978-3531-94211-7_4]. 
Górczyńska, Magdalena 2015: Gentryfikacja w polskim kontekście: krytyczny przegląd koncepcji wyjaśniających. [Gentrification in Polish context: a critical overview of explanatory concepts.] In: Przegląd Geograficzny 87,4: 589-611 [doi: 10.7163/ PrzG.2015.4.2].

Grabkowska, Maja 2015: Between gentrification and reurbanisation: The participatory dimension of bottom-up regeneration in Gdańsk, Poland. In: Geografie 120,2: 210-225.

Haase, Annegret et al. 2005: Reurbanisation of Inner-City Areas in European Cities. In: Sagan, Iwona; Smith, David (Eds.): Society, economy, environment - towards the sustainable city. Gdansk, Poznan: 75-91.

Haase, Annegret et al. 2010: Emergent spaces of reurbanisation: exploring the demographic dimension of inner-city residential change in a European setting. In: Population, Space and Place 16,5: 443-463 [doi: 10.1002/psp.603].

Haase, Annegret et al. (Eds.) 2011: Residential change and demographic challenge. The inner city of East Central Europe in the 21st century. Farnham/Burlington: Ashgate.

Haase, Annegret et al. 2012: Reurbanizing Leipzig (Germany): Context Conditions and Residential Actors (2000-2007). In: European Planning Studies 20,7: 1173-1196 [doi: 10.1080/09654313.2012.674349].

Haase, Annegret et al. 2014: Conceptualizing Urban Shrinkage. In: Environment and Planning A: Economy and Space 46,7: 1519-1534 [doi: 10.1068/a46269].

Haase, Annegret; Rink, Dieter 2015: Inner-city transformation between reurbanization and gentrification: Leipzig, eastern Germany. In: Geografie 120,2: 226-250.

Hall, Peter; Hay, Dennis 1980: Growth Centres in the European Urban System. Heinemann Educational, London.

Halleux, Jean-Marie; Marcinczak, Szymon; van der Krabben, Erwin 2012: The adaptive efficiency of land use planning measured by the control of urban sprawl. The cases of the Netherlands, Belgium and Poland. In: Land Use Policy 29,4: 887-898 [doi: 10.1016/j. landusepol.2012.01.008]

Hampl, Martin; Kühnl, Kare/ 1993: Migratory trends in former Czechoslovakia. Acta Universitatis Carolinae. In: Geographica 28,1: 53-71.

Helbrecht, I/se 1996: Die Wiederkehr der Innenstädte. Zur Rolle von Kultur, Kapital und Konsum im Prozess der Gentrification. In: Geographische Zeitschrift 84,1: 1-15.

Herfert, Günter 2007: Regionale Polarisierung der demographischen Entwicklung in Ostdeutschland - Gleichwertigkeit der Lebensverhältnisse? In: Raumforschung und Raumordnung 65,5: 435-455 [doi: 10.1007/BF03183833].

Holm, Andrej 2012: Paradoxien und Begleiterscheinungen der Reurbaniserung. In: Brake, Klaus; Herfert, Günter (Eds.): Reurbanisierung. Materialität und Diskurs in Deutschland. Wiesbaden: Springer: 239-256 [doi: 10.1007/978-3-531-94211-7_14].

Ilík, Jan; Ouředníček, Martin 2007: Karlín a jeho proměny v souvislostech postsocialistické transformace Prahy. In: Geografie 112,3: 292-314.

Kabisch, Nadja; Haase, Dagmar; Haase, Annegret 2010: Evolving reurbanisation? Spatio-temporal dynamics as exemplified by the east German city of Leipzig. In: Urban Studies 47,5: 967-990 [doi: 10.1177/0042098009353072].

Kabisch, Nadja; Haase, Dagmar 2011: Diversifying European agglomerations: evidence of urban population trends for the $21^{\text {st }}$ century. In: Population, Space and Place 17,3, 236-253 [doi: 10.1002/psp.600]. 
Kabisch, Nadja; Haase, Dagmar; Haase, Annegret 2012: Urban Population Development in Europe, 1991-2008: The Examples of Poland and the UK. In: International Journal of Urban and Regional Research 36,6: 1326-1348 [doi: 10.1111/j.1468-2427.2012.01114.x].

Kährik, Anneli et al. 2016: What attracts people to inner city areas? The cases of two post-socialist cities in Estonia and the Czech Republic. In: Urban Studies 53,2: 355-372 [doi: 10.1177/0042098014567444].

Kajdanek, Katarzyna 2012: Suburbanizacja po polsku. [Polish-style suburbanization]. Cracow: Nomos.

Karsten, Lia 2014: From Yuppies to Yupps: Family Gentrifiers Consuming Spaces and Re-inventing Cities. In: Tijdschrift voor Economische en Sociale Geografie 105,2: 175 188 [doi: 10.1111/tesg.12055].

Klaassen, Leo; Scimeni, Gabriel 1981: Theoretical issues in urban dynamics. In: Klaassen, Leo et al. (Eds.): Dynamics of Urban Development. Aldershot: Gower: 8-28.

Klusáček, Petr; Vaishar, Antonín 2008: Současné urbanizační pochody a obytné prostředí jako součást kvality života ve vnitřních částech evropských velkoměst. In: Geographia Slovaca 25: 145-157.

Klusáček, Petr et al. 2009: Urban Development In Selected Czech And Austrian City Regions. Acta Universitatis Palackianae Olomucensis. In: Geographica 40,2: 27-57.

Krejčí, Tomáš et al. 2011: Spatial differentiation of selected processes connected to the second demographic transition in post-socialistic cities (the examples of Brno and Ostrava, Czech Republic). In: Moravian Geographical Reports 19,2: 39-50.

Kubeš, Jan 2009: Poloha, struktura, infrastruktura a obraz Českých Budějovic a Českobudějovické aglomerace. In: Kubeš, Jan et al. (Eds.): Urbánní geografie Českých Budějovic a Českobudějovické aglomerace I., Ustav vedy a výskumu Univerzity Mateja Bela v Banskej Bystrici: 51-105.

Kubeš, Jan 2015: Analysis of regulation of residential suburbanisation in hinterland of post-socialist "one hundred thousands" city of České Budějovice. In: Bulletin of Geography, Socio-Economic Series 27,27: 109-131 [doi: 10.1515/bog-2015-0008].

Kujath, Hans Joachim 1988: Reurbanisierung? - Zur Organisation von Wohnen und Leben am Ende des städtischen Wachstums. In: Leviathan 16,1: 23-43.

Kujath, Hans-Joachim 2012: Reurbanisierung des Wissens - zur Herausbildung von Metropolregionen unter dem Einfluss der Wissensökonomie. In: Brake, Klaus; Herfert, Günter (Eds.): Reurbanisierung. Materialität und Diskurs in Deutschland. Wiesbaden: Springer: 216-238 [doi: 10.1007/978-3-531-94211-7_13].

Kunc, Josef et al. 2014: Perception of urban renewal: Reflexions and coherences of socio-spatial patterns (Brno, Czech Republic). In: Geographia Technica 9,1: 66-77.

Książek, Słavomir; Suszczewicz, Michał 2017: City profile: Wrocła. In: Cities 65, 51-65 [doi: 10.1016/j.cities.2017.03.001].

Lever, Walter Frederick 1993: Reurbanisation - the policy implications. In: Urban Studies 30,2: 267-284 [doi: 10.1080/00420989320080281].

Lorens, Piotr (Ed.) 2007: Rewitalizacja miast w Polsce. Pierwsze doświadczenia. [Urban regeneration in Poland. First experiences.] Warszawa: Urbanista.

Marcińczak, Szymon; Sagan, Iwona 2011: The socio-spatial restructuring of Łódź, Poland. Urban Studies 48,9: 1789-1809 [doi: 10.1177/0042098010379276].

Marcińczak, Szymon; Gentile, Michael; Stepniak, Marcin 2013: Paradoxes of (Post)Socialist Segregation: Metropolitan Sociospatial Divisions under Socialism and after in Poland. In: Urban Studies 34,3: 327-352 [doi: 10.1080/02723638.2013.778667]. 
Metropolitní Plán 2016: Prague Institute of Planning and Development [http://plan. iprpraha.cz/cs/metropolitni-plan, 23.03.2018].

Murzyn-Kupisz, Monika; Szmytkowska, Magdalena 2015: Studentification in the postsocialist context: The case of Cracow and the Tri-City (Gdansk, Gdynia and Sopot). In: Geografie 120,2: 188-209.

Musil, Jiri 1977: Urbanizace v socialistických zemích. Praha: Svoboda.

Myers, Dowell 1990: Housing Demography. Linking Demographic Structure and Housing Markets. Madison: University of Wisconsin Press.

Mulder, Clara H.; Dieleman, Frans M. 2002: Living arrangements and housing arrangements: Introduction to the special issue. In: Journal of Housing and the Built Environment 17,3: 209-213 [doi: 10.1023/A:1020202702602].

Nuissl, Henning; Rink, Dieter 2005: The 'production' of urban sprawl in eastern Germany as a phenomenon of post-socialist transformation. In: Cities 22,2: 123-134 [doi: 10.1016/j.cities.2005.01.002].

Nyström, Jan 1992: The Cyclical Urbanization Model. A critical Analysis. Geografiska Annaler B 74,2: 133-144 [doi: 10.1080/04353684.1992.11879637].

Ouředníček, Martin et al. 2015: The reurbanisation concept and its utility for contemporary research on post-socialist cities: The case of the Czech Republic. In: Moravian Geographical Reports 23,4: 26-35 [doi: 10.1515/mgr-2015-0022].

Parysek, Jerzy; Mierzejewska, Lidia 2005: Między dezurbanizacją a reurbanizacją: nowe oblicze urbanizacji w Polsce [Between disurbanization and reurbanisation: new face of urbanization in Poland]. In: Jażdżewska, Iwona (Ed.): XVIII Konwersatorium Wiedzy o Mieście, Współczesne procesy urbanizacji i ich skutki. Łódź: Uniwersytet Łódzki: 47-56.

Power, Anne et al. 2010: Phoenix cities: The fall and rise of great industrial cities. University of Chicago Press.

Pumain, Denise 2006: Alternative explanations of hierarchical differentiation in urban systems. In: Pumain, Denise (Ed.): Hierarchy in natural and social sciences. Springer: 169-222 [doi: 10.1007/1-4020-4127-6].

Radzimski, Adam 2011: Rola planowania miejskiego na przykładzie budownictwa mieszkaniowego w Poznaniu [The role of urban planning on the example of residential construction in Poznań). In: Studia KPZK 134: 178-203.

Radzimski, Adam 2014: Subsidized mortgage loans and housing affordability in Poland. In: GeoJournal 79,4: 467-494 [doi: 10.1007/s10708-014-9533-2].

Radzimski, Adam 2015: Między miastem kurczącym się a reurbanizacją. Zróżnicowanie rozwoju miast w Niemczech w latach 1995-2012. [Between the shrinking city and reurbanisation. Differentiation of urban development in Germany in the years 1995-2012.] In: Przegląd Geograficzny 87,4: 659-682 [doi: 10.7163/PrzG.2015.4.5].

Rink, Dieter et al. 2012: From Long-Term Shrinkage to Re-Growth? The Urban Development Trajectories of Liverpool and Leipzig. In: Built Environment 38,2: 162-178 [doi: 10.2148/benv.38.2.162].

Rink, Dieter 2015: Leipzig - Stadt der Extreme. In: Leipziger Blätter - Sonderheft 1000 Jahre Leipzig: 4-7.

Rumpel, Petr; Slach, Ondrej 2012: Je Ostrava „smrštujícím se městem“? In: Sociologický Časopis/Czech Sociological Review 48,5: 859-878. 
Seidenglanz, Daniel; Toušek, Václav; Chvátal, Filip 2013: Odborná analýza vývoje počtu osob oficiálně neregistrovaných ve městě brně, 2013. Kvalifikovaný odhad vývoje celkového počtu obyvatel Brna do roku 2025. Masarykova univerzita, Př́rodovědecká fakulta, Geografický ústav, Centrum pro regionální rozvoj, Brno.

Šimon, Martin 2014: Exploring counterurbanisation in a post-socialist context: Case of the Czech Republic. In: Sociologia Ruralis 54,2: 117-142 [doi: 10.1111/j.14679523.2012.00576.x].

Špačková, Petra; Ouředníček, Martin 2012: Spinning the web: New social contacts of Prague's suburbanites. In: Cities 29,5: 341-349 [doi: 10.1016/j.cities.2011.09.002].

Špačková, Petra; Pospíšilová, Lucie; Ouředníček Martin 2016a: Long-term Development of Socio-spatial Differentiation in Socialist and Post-socialist Prague. In: Sociologický časopis 52,6: 821-860 [doi: 10.13060/00380288.2016.52.6.288].

Špačková, Petra; Dvořáková, Nina; Tobrmanová, Martina 2016b: Residential satisfaction and intention to move: the case of Prague's new suburbanites. In: Geografiska Annaler B98,4: 331-348 Pages 331-348.

Sojkin, Bogdan; Bartkowiak, Pawel; Skuza, Agnieszka 2012: Determinants of higher education choices and student satisfaction: The case of Poland. In: Higher Education 63,5: 565-581 [doi: 10.1007/s10734-011-9459-2].

Steinführer, Annett 2006: The Urban Transition Of Inner City Areas Reconsidered (A German-Czech Comparison). In: Moravian Geographical Reports 14,1: 3-16.

Steinführer, Annett et al. 2010: Population Decline in Polish and Czech Cities during Post-socialism? Looking Behind the Official Statistics. In: Urban Studies 47,11: 23252346 [doi: 10.1177/0042098009360224].

Storper, Michael; Manville, Michael 2006: Behaviour, preferences and cities: urban theory and urban resurgence. In: Urban Studies 43,8: 1247-1274 [doi: 10.1080/00420980600775642].

Sýkora, Luděk 2006: Urban development, policy and planning in the Czech republic and Prague. In: Altrock, Uwe et al. (Eds): Spatial Planning and Urban Development in the New EU Member States: From Adjustment to Reinvention. Farnham: Ashgate Publishing: 113-140.

Sýkora, Luděk; Posová, Darina 2011: Formy urbanizace: Kritické zhodnocení modelu stadií vývoje měst a návrh alternativní metody klasifikace forem urbanizace. In: Geografie 116,1: 1-22.

Sýkora, Luděk; Mulíček, Ondřej 2014: Prague: Urban Growth and Regional Sprawl. In: Stanilov, Kiril; Sýkora, Luděk (Eds.): Confronting Suburbanization: Urban Decentralization in Postsocialist Central and Eastern Europe. Chichester: Wiley Blackwell: 133-162 [doi: 10.1002/9781118295861.ch5].

Temelová, Jana 2007: Flagship developments and the physical upgrading of the post-socialist inner city: The Golden Angel project in Prague. In: Geografiska Annaler 89B,2: 169-181 [doi: 10.1111/j.1468-0467.2007.00246.x].

Turok, Ivan; Mykhnenko, Vlad 2007: The trajectories of European cities, 1960-2005. In: Cities 24,3: 165-182 [doi: 10.1016/j.cities.2007.01.007].

Wiechmann, Thorsten 2008: Errors expected - aligning urban strategy with demographic uncertainty in shrinking cities. In: International Planning Studies 13,4: 431-446 [doi: 10.1080/13563470802519097].

Wolff, Manuel et al. 2016: The impact of urban regrowth on the built environment. In: Urban Studies 54,12: 2683-2700 [doi: 10.1177/0042098016658231]. 
Wolff, Manuel; Wiechmann, Thorsten 2017: Urban growth and decline: Europe's shrinking cities in a comparative perspective 1990-2010. In: European Urban and Regional Studies [doi: 10.1177/0969776417694680].

Ziobrowski, Zygmunt; Jarczewski, Wojciech 2010: Rewitalizacja miast polskich: diagnoza. Cracow: Institute of Urban Development.

Dr. Annegret Haase ( $\varangle)$. Helmholtz Centre for Environmental Research - UFZ, Department of Urban and Environmental Sociology. Leipzig, Germany. E-mail: annegret.haase@ufz.de

URL: http://www.ufz.de/index.php?en=1650

Manuel Wolff. Humboldt Universität zu Berlin, Department of Geography/Lab of Landscape Ecology. Berlin, Germany. E-mail: manuel.wolff@hu-berlin.de URL: http://www.ufz.de/index.php?en $=38796$

Helmholtz Centre for Environmental Research - UFZ, Department of Urban and Environmental Sociology. Leipzig, Germany.E-mail: manuel.wolff@ufz.de URL: http://www.geographie.hu-berlin.de/Members/Wolff_Manuel

Dr. Petra Špačková. Charles University, Faculty of Science, Department of Social Geography and Regional Development. Prague, Czech Republic.

E-mail: petra.spackova@natur.cuni.cz

URL: http://urrlab.cz/en/profile/petra-spackova

Dr. Adam Radzimski. Adam Mickiewicz University in Poznań, Faculty of Geographical and Geological Sciences, Institute of Socio-Economic Geography and Spatial Management. Poznań, Poland. E-mail: adam.radzimski@amu.edu.pl

URL: http://igsegp.amu.edu.pl/pracownicy/dr-adam-radzimski-adiunkt/ 


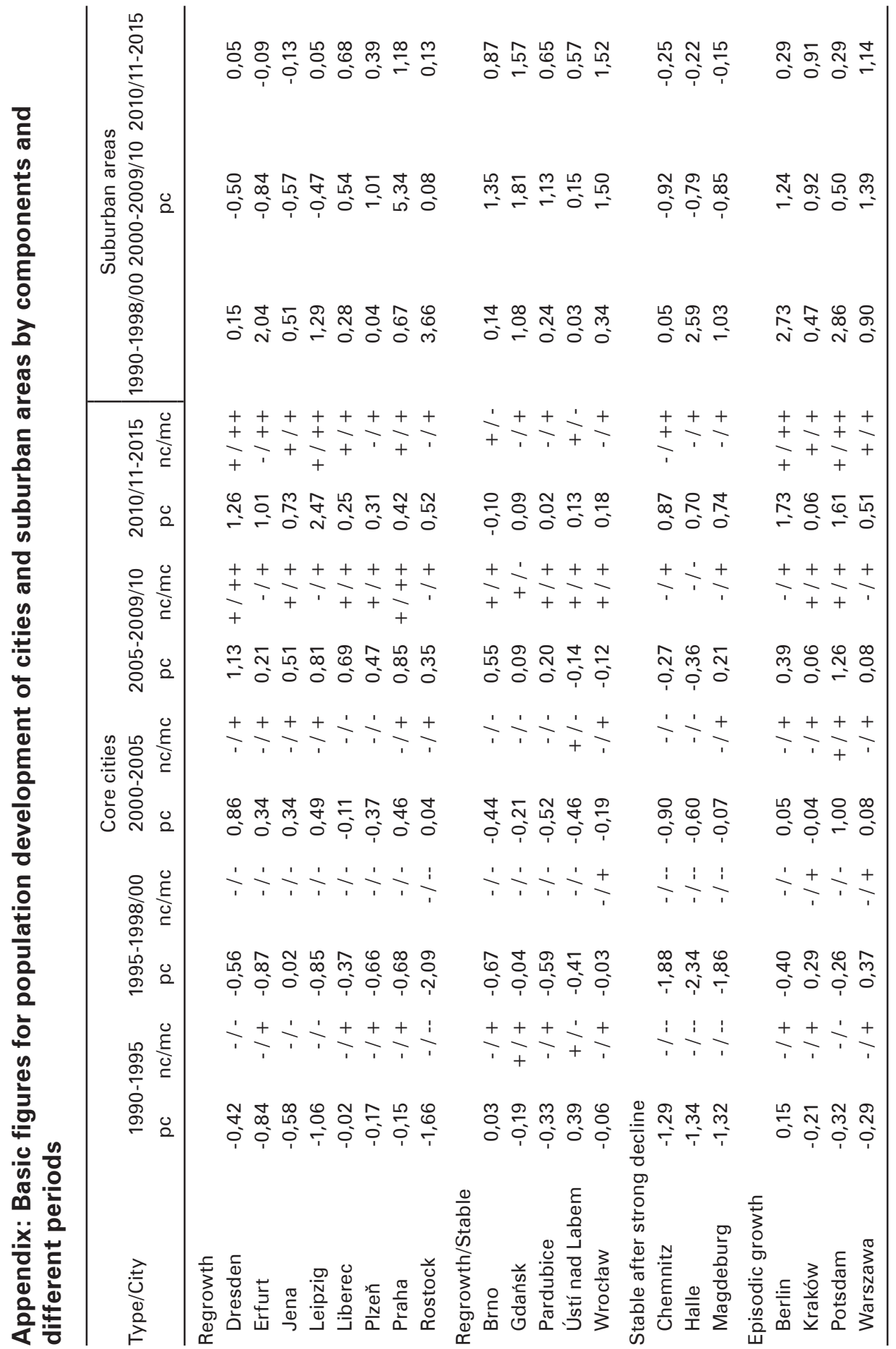



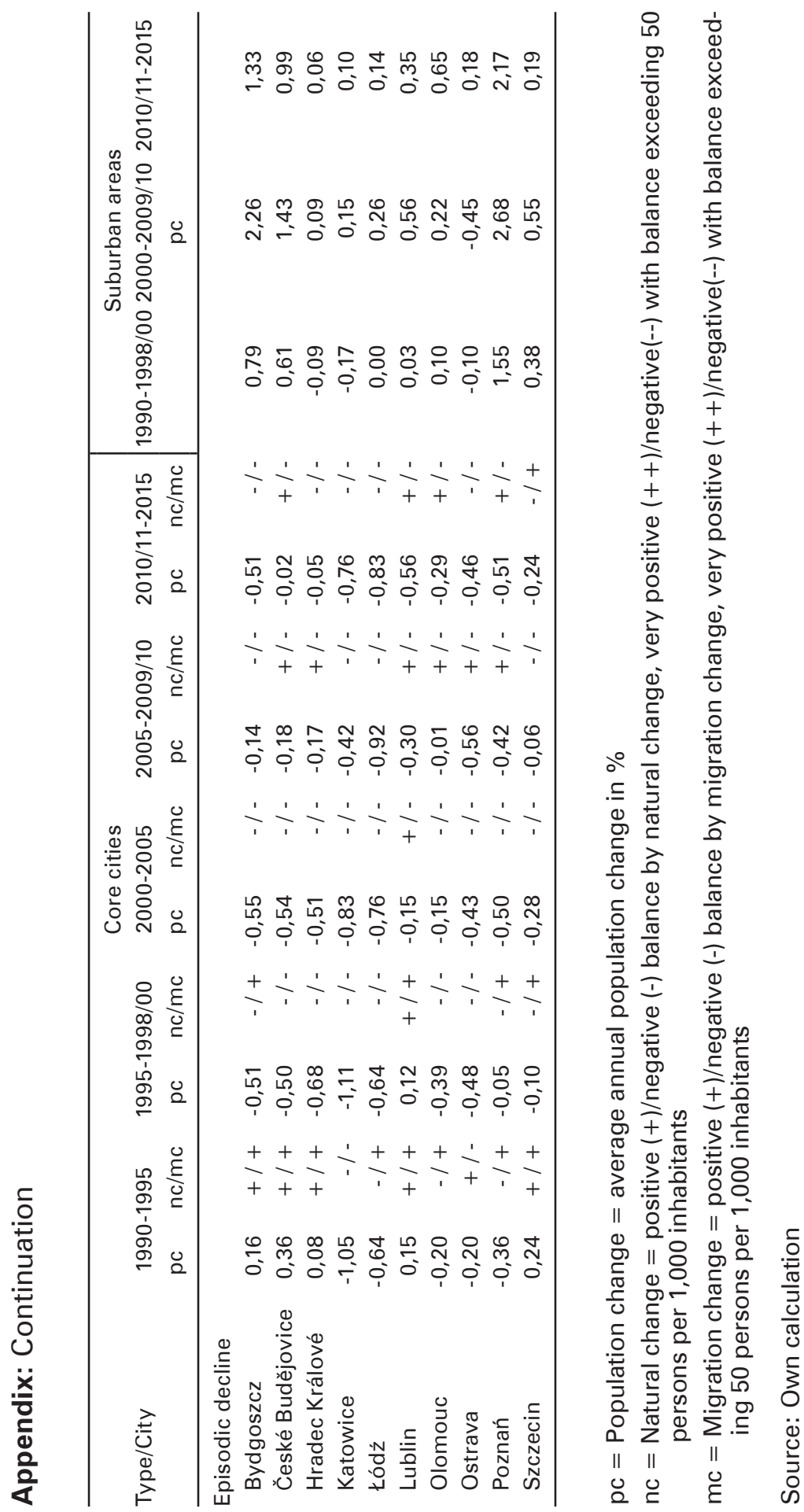


\section{Comparative Population Studies}

wWW.comparativepopulationstudies.de

ISSN: 1869-8980 (Print) - 1869-8999 (Internet)

\section{Published by}

Prof. Dr. Norbert F. Schneider

Federal Institute for Population Research D-65180 Wiesbaden / Germany

\section{(cc) BY-SA}

2017

\section{Managing Editor}

Frank Swiaczny

\section{Assistant Managing Editor}

Katrin Schiefer

\section{Copy Editor}

(Selected Articles in German)

Dr. Evelyn Grünheid

\section{Layout}

Beatriz Feiler-Fuchs

E-mail: cpos@bib.bund.de

\section{Scientific Advisory Board}

Paul Gans (Mannheim)

Karsten Hank (Cologne)

Johannes Huinink (Bremen)

Michaela Kreyenfeld (Rostock)

Marc Luy (Vienna)

Notburga Ott (Bochum)

Peter Preisendörfer (Mainz)

Nikola Sander (Groningen)

Zsolt Spéder (Budapest)

\section{Board of Reviewers}

Martin Abraham (Erlangen)

Laura Bernardi (Lausanne)

Hansjörg Bucher (Bonn)

Claudia Diehl (Konstanz)

Andreas Diekmann (Zurich)

Gabriele Doblhammer-Reiter (Rostock)

Jürgen Dorbritz (Wiesbaden)

Anette Eva Fasang (Berlin)

E.-Jürgen Flöthmann (Bielefeld)

Alexia Fürnkranz-Prskawetz (Vienna)

Beat Fux (Salzburg)

Joshua Goldstein (Berkeley)

Sonja Haug (Regensburg)

Hill Kulu (Liverpool)

Aart C. Liefbroer (The Hague)

Kurt Lüscher (Konstanz)

Emma Lundholm (Umeå)

Nadja Milewski (Rostock)

Dimiter Philipov (Vienna)

Roland Rau (Rostock)

Tomáš Sobotka (Vienna)

Jeroen Spijker (Barcelona)

Olivier Thévenon (Paris)

Helga de Valk (Brussels)

Heike Trappe (Rostock)

Michael Wagner (Cologne) 